\title{
The Utilisation and Perceived Value of Archives New Zealand's Recordkeeping Standards by Public Sector Recordkeepers
}

\author{
by \\ Grace Elizabeth Currie
}

Submitted to the School of Information Management, Victoria University of Wellington, in partial fulfilment of the requirements for the degree of Master of Information Studies

June 2011 


\section{ACKNOWLEDGEMENTS}

Sincere thanks to my supervisor Gillian Oliver for her guidance and friendly face.

Thanks also to Andy for putting up with me throughout this process. 


\section{ConTEnTS}

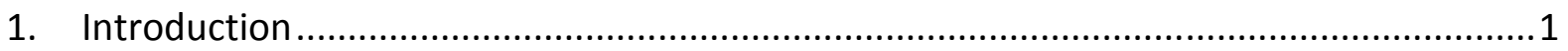

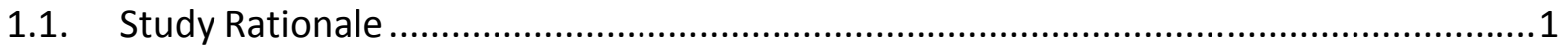

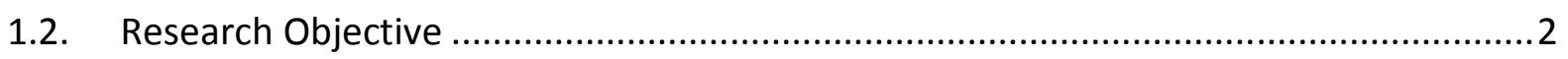

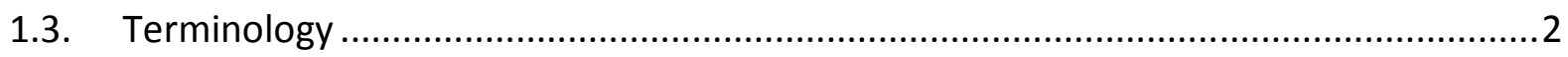

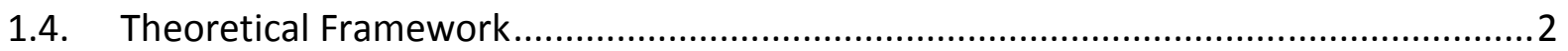

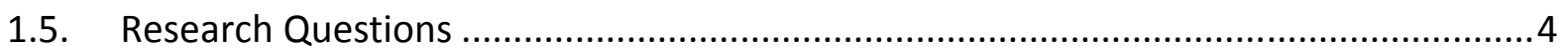

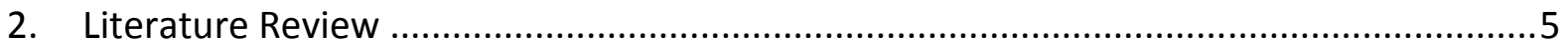

2.1. Summary of the Available Literature .....................................................................

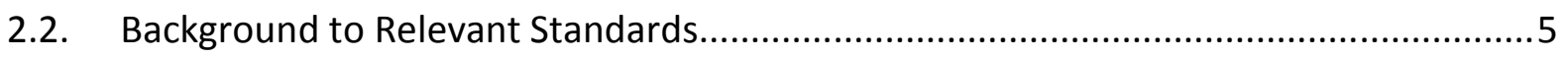

2.3. The Desirability and Importance of Recordkeeping Standards ................................ 6

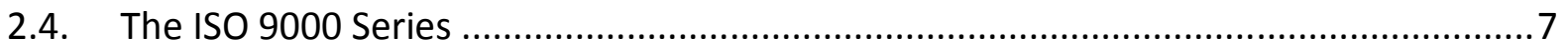

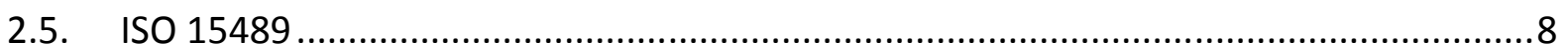

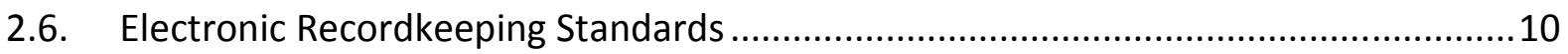

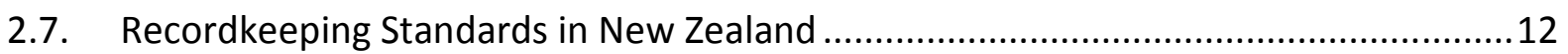

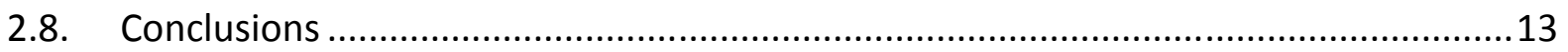

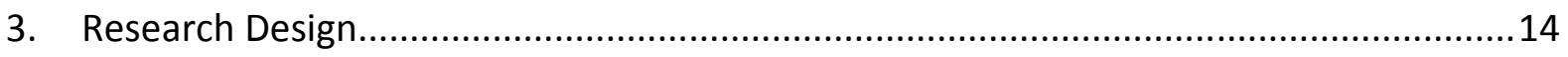

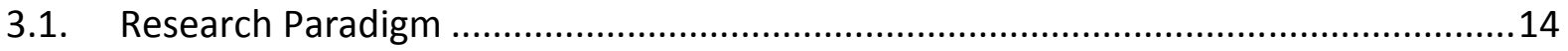

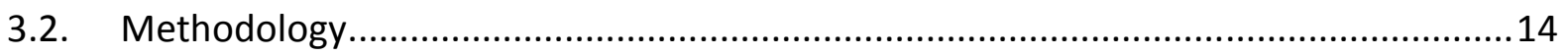

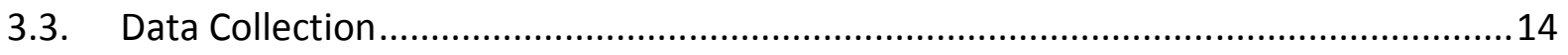

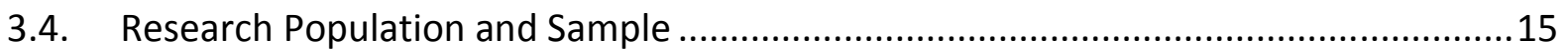

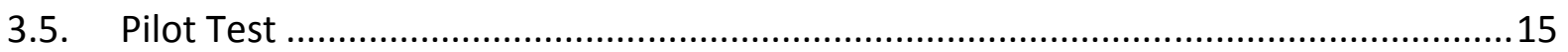

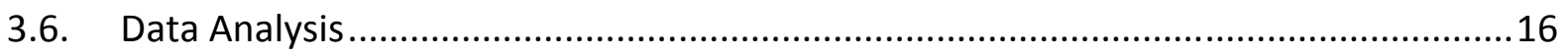

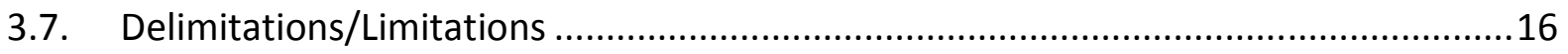

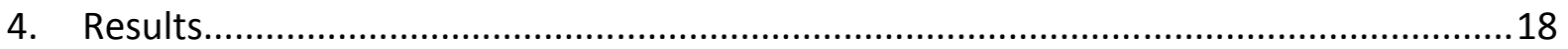

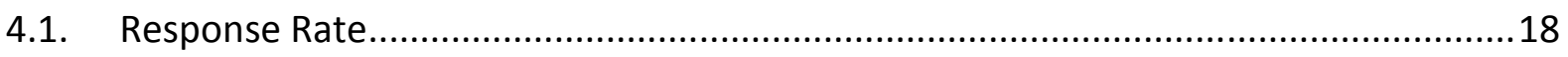

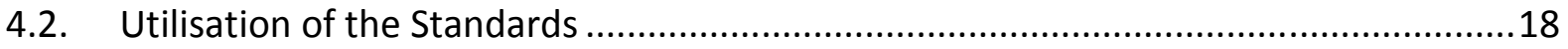

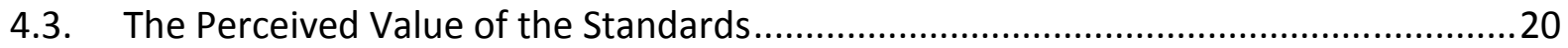

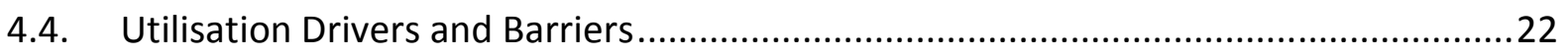

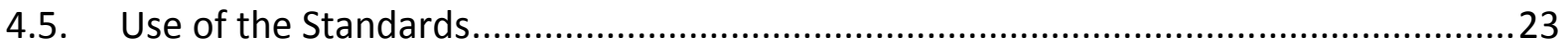

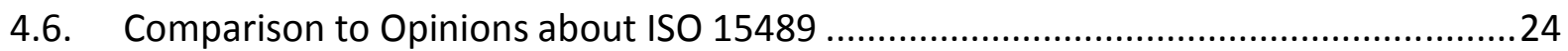




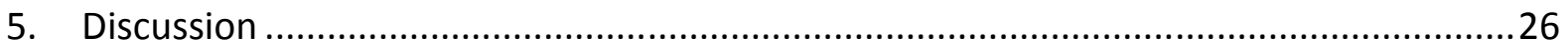

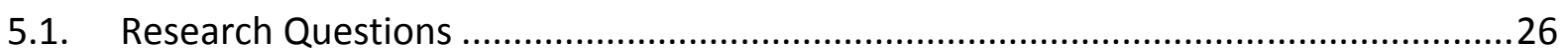

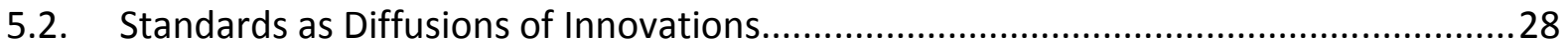

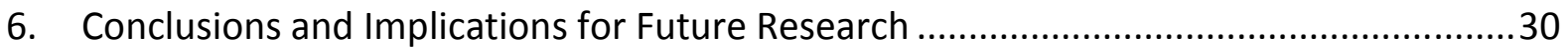

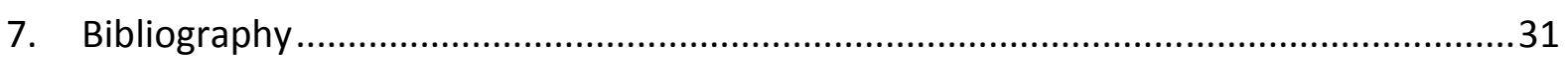

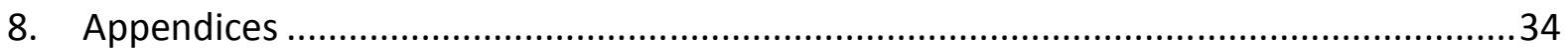

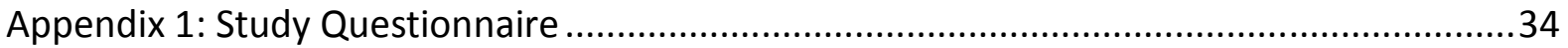

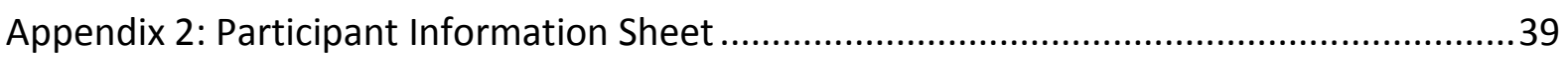

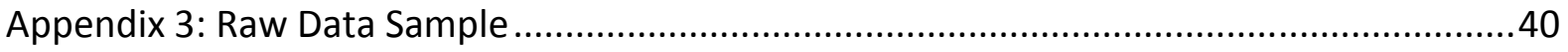

\section{Tables}

1: Standards released by Archives New Zealand under the Public Records Act 2005........1

2: Standard utilisation in participants' organisations...................................................................18

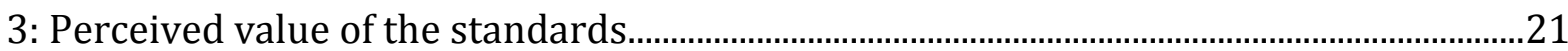

4: Organisational drivers for standard utilisation...................................................................22

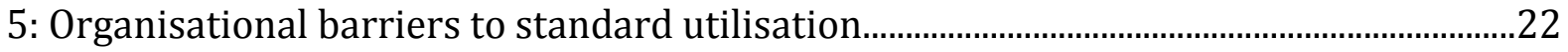

6: Reasons given for not utilising the standards in organisations...........................................23

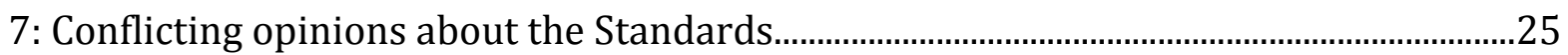

\section{Graphs}

1: Familiarity with and utilisation of the standards................................................................

2: Utilisation of mandatory and discretionary standards......................................................20

3: Organisational Impact of Standard Utilisation........................................................................21

4: How the standards are being used by recordkeepers............................................................24 


\section{Abstract}

Archives New Zealand has issued and revised seven recordkeeping standards since the passing of the Public Records Act 2005, four of which are mandatory compliance standards for all public offices and local authorities. Public sector recordkeepers are charged with achieving their organisations' compliance with the Public Records Act but no research has been done into the utilisation and perceived value of these standards by this group. This project aimed to reveal how widespread utilisation of Archives New Zealand's recordkeeping standards is and how valuable public sector recordkeepers believe the standards are by seeking evidence of utilisation of the standards, reasons behind this utilisation or lack thereof, and perceived drivers and/or barriers to the standards' utilisation. A quantitative survey research approach was taken to obtain data from public sector recordkeepers. The research found that the standards are being used by many recordkeepers and for multiple purposes within organisations. The mandatory standards are the most utilised and compliance to the Public Records Act the biggest driver behind utilisation. Overall the standards are deemed valuable, but opinions are conflicting concerning the style and content of the standards. Further research into this area is recommended to provide more detailed results about the standards as individual entities. 


\section{INTRODUCTION}

\subsection{STUDY RATIONALE}

The Public Records Act (PRA) 2005 established Archives New Zealand, through its Chief Archivist, as the national institution charged with issuing standards to direct and support the responsible creation, maintenance, disposal and accessibility of public and local authority records to ensure Government accountability and integrity through full and accurate records of its affairs. Archives New Zealand has since released and revised seven recordkeeping standards, four of which are mandatory for all public offices (excluding schools) and local authorities, and three which are considered standards of discretionary best practice.

\begin{tabular}{|l|l|l|}
\hline Standard and Release Date & \multicolumn{1}{|c|}{ Summary } & \multicolumn{1}{|c|}{ Status } \\
\hline $\begin{array}{l}\text { S2: Storage Standard } \\
\text { (June 2007) }\end{array}$ & $\begin{array}{l}\text { Specifies minimum requirements for storage } \\
\text { of physical records and archives. }\end{array}$ & Mandatory \\
\hline $\begin{array}{l}\text { S7: Create and Maintain } \\
\text { Recordkeeping Standard (June } \\
\text { 2008) }\end{array}$ & $\begin{array}{l}\text { Specifies minimum requirements for the } \\
\text { creation and maintenance of records. }\end{array}$ & Mandatory \\
\hline $\begin{array}{l}\text { S8: Electronic Recordkeeping } \\
\text { Metadata Standard }\end{array}$ & $\begin{array}{l}\text { Specifies minimum requirements for creating } \\
\text { and managing recordkeeping metadata in } \\
\text { electronic environments. }\end{array}$ & Mandatory \\
\hline $\begin{array}{l}\text { S9: Disposal Standard } \\
\text { (November 2010) }\end{array}$ & $\begin{array}{l}\text { Specifies minimum requirements } \\
\text { determining how public offices and local } \\
\text { authorities dispose of records. }\end{array}$ & Mandatory \\
\hline $\begin{array}{l}\text { S4: Access Standard } \\
\text { (August 2006) }\end{array}$ & $\begin{array}{l}\text { Sets out legislative requirements and } \\
\text { guidance on best practices for the provision } \\
\text { of access to public archives and local } \\
\text { authority archives. }\end{array}$ & Discretionary \\
\hline $\begin{array}{l}\text { S5: Digital Recordkeeping } \\
\text { Standard } \\
\text { (November 2010) }\end{array}$ & $\begin{array}{l}\text { Establishes principles and good practice } \\
\text { requirements for creating and managing } \\
\text { records in digital systems. }\end{array}$ & Discretionary \\
\hline $\begin{array}{l}\text { S6: Digitisation Standard } \\
\text { (January 2007) }\end{array}$ & $\begin{array}{l}\text { Sets out requirements for digitisation } \\
\text { processes for public offices and local } \\
\text { authorities. }\end{array}$ & Discretionary \\
\hline
\end{tabular}

Table 1: Standards released by Archives New Zealand under the Public Records Act 2005 (All standards are available in PDF or HTML format from Archives New Zealand's Continuum Resource Kit: http://archives.govt.nz/advice/continuum-resource-kit/publications-publication-type) 
These standards dictate recordkeeping principles and requirements and are designed as tools to assist the records management professionals charged with achieving their organisations' compliance with the PRA. Considering how public sector organisations under the PRA are expected to comply with the four of these standards that are mandatory, and that the Public Records Act 2005 Audit Programme, run by Archives New Zealand, is currently in its first year, it is disappointing no research has been done that explores the relationship between public sector recordkeepers and these standards. Such research would be provide illumination on if and how recordkeepers are using the standards, and whether the standards are valuable as tools to help public offices meet their obligations under the PRA.

\subsection{RESEARCH OBJECTIVE}

The objective of this research project was to reveal how widespread utilisation of Archives New Zealand's recordkeeping standards is and how valuable public sector recordkeepers believe the standards are. To do this the project sought evidence of utilisation of the standards, reasons behind this utilisation or lack thereof, and perceived drivers and/or barriers to the standards' utilisation. These areas formed the basis of the research questions in section 1.5 .

\subsection{TERMINOLOGY}

The terms recordkeeping and recordkeepers were employed throughout the project because they align with Archives New Zealand's standards terminology and with the terminology used by the international standard for recordkeeping, ISO 15489. Archives New Zealand's standards are referred to collectively as "the standards" throughout the project.

\subsection{THEORETICAL FrameWORK}

The project was informed by Everett Rogers' theory of diffusion of innovations which maps and assesses the processes through which people and groups in society adopt new ideas (Rogers, 2003). This research was not designed to test this theory, but employed it as a framework to explore the utilisation of Archives New Zealand's standards by approaching them as new innovations or ideas, and viewing users of the standards, 
whether individual public sector recordkeepers or their organisations, as adopters of innovations.

Building on the earlier musings of European sociologists and anthropologists, Rogers populised this theory with the first publication of Diffusion of Innovations in 1962, in which he conceptualised the process of diffusion of new ideas (innovations) throughout societies. Rogers defined diffusion as "the process in which an innovation is communicated through certain channels over time among the members of a social system" (Rogers, 2003, p. 5). By social system he meant any set of interrelated units engaged in joint problem solving to accomplish a common goal, for example, an organisation, corporation or any other societal grouping with a shared objective (Rogers, 2003, p. 23).

Rogers proposed that many new ideas take years to be adopted from the time they come available, and that people consider five primary attributes of innovations during the decision making processes involved in adopting new ideas. These are:

- Relative advantage: how the innovation or idea compares with the one it supersedes

- Compatibility: how it fits with existing values and past experiences

- Complexity: how difficult it is to understand and use

- Trialability: can the innovation or idea be experimented with

- Observability: how successfully it has been adopted by others (Rogers, 2003, pp. 15-16).

Adopters of innovation are also categorised by Rogers on the basis of innovativeness into five groupings: innovators (2.5\%), early adopters (13.5\%), early majority (34\%), late majority (34\%) and laggards (16\%) (Rogers, 2003, p. 281). How the results of the project relate to Rogers' categories of attributes and adoption of innovations is discussed in section 5.3 . 


\subsection{RESEARCH QUESTIONS}

The research questions for this project comprised of one primary research question (PQ) and four subsidiary questions (SQ):

PQ: How extensive is usage of Archives New Zealand's recordkeeping standards?

SQ1: To what extent are these standards perceived as valuable recordkeeping tools among public sector recordkeepers?

SQ2: What drivers and/or barriers exist that affect the utilisation of the standards?

SQ3: How are public sector recordkeepers using the standards?

SQ4: How do public sector recordkeepers' opinions concerning the standards compare to opinions voiced in the literature regarding ISO 15489? 


\section{LITERATURE REVIEW}

\subsection{Summary OF THE AVAilable Literature}

Literature on recordkeeping standards in New Zealand is scarce, and when reviewing the literature on recordkeeping standards in an international context, a major deficiency is apparent; with the exceptions of the work of McLeod and Child (2003 \&2005), and of Tough (2004) concerning ISO 15489, there has been very little actual research published about the uptake, utilisation and perceived value of recordkeeping standards. In contrast, there is much literature concerning the history and development of standards, their desirability to the recordkeeping profession, and case studies where such standards have been applied to organisations. This lack of research into utilisation of recordkeeping standards is a conspicuous deficiency; however, there has been much research undertaken into the uptake and implementation of quality standards, especially the ISO 9000 series that have a recordkeeping component, which are relevant to this area of study.

\subsection{BACKGROUND TO RELEVANT STANDARDS}

There are several standards that have affected recordkeeping practices in the last twenty years. Some of these are recordkeeping standards and some have another primary purpose but possess recordkeeping components. The ISO 9000 series of quality management standards were the first international standards to create a significant wave in recordkeeping literature. First published in 1987 and now adopted by over one million organisations in 176 countries (International Organisation for Standardization, 2011), this series of standards emphasised the importance of proper management of quality records, and necessitated records meet the requirements of an independent auditor for the organisation to achieve ISO 9000 certification (Stephens, 1996).

The Australian standard AS 4390 Records Management was the next standard to make a significant impact. The first ever national standard for records management, AS 4390 went on to become the basis for ISO 15489: Information and Documentation - Records Management, the world's first international recordkeeping standard. Archives New Zealand endorses ISO 15849 as a code of best practice for government recordkeeping 
and it forms the basis for their 2008 Create and Maintain Recordkeeping Standard (Archives New Zealand, n.d.).

There are also various standards related to electronic records that have been the subject of much debate in the literature. The most prominent of these include the US Department of Defence's 1997 DoD 5015.2 Design Criteria Standard for Electronic Records Management Applications, the European Commission's 2001 Model Requirements for the Management of Electronic Records (MoReq) 2001 (rereleased as MoReq2 in 2008), and ISO 23081 Metadata for Records.

\subsection{ThE DESIRABILITY AND IMPORTANCE OF RECORDKEEPING STANDARDS}

A primary theme that emerges from the literature is that recordkeeping standards are highly desirable and important to the records profession. This importance can be categorised into two areas: the importance of the content of the standards, and the importance of these standards to the records management profession itself.

Recordkeeping standards aim to create an environment of best practice, ensuring interoperability and establishing a common language among practitioners (Pember, 2006, p. 26). Hofman make a strong case for their necessity in a modern environment where interconnectivity of organisations and pressure for access to information sources makes standardisation essential (Hofman, 2006, p.37). The international standard ISO 15489 has been described as "a statement of good practice in records management which records managers should find useful" (Healy, 2001, p. 140), "a strong and comprehensive document" (Cumming, 2003) that can "help resolve the who, what, when, where, and why" (Jones, 2003, p. 70) of recordkeeping. Hofman describes it as providing "an excellent framework and a broad view of the principles and core issues" but is one of few to stress the importance of recordkeepers being aware of all standardisation options and to align standards with their core business practices (Hofman, 2006, pp.38-39).

These positive statements about ISO 15489 appear rather unenthusiastic compared with the comments in the literature on the importance of standards to the records management profession. This concept is recurrently apparent throughout the literature. 
Wise and Stamoolis (1993) asserted that the ISO 9000 series would result in enhanced positions for records professionals and enhanced opportunities for the profession as a whole. Stephens (2000, p. 70) described them of being capable of "stimulating globalised records management activities" and Brumm (1996, p. 6) talked of "the critical importance of ISO 9000 to the records management profession". Later, Stephens and Roberts claimed AS4390 had "the potential to elevate records management as a professional business practice in a way that nothing else can" (Stephens \& Roberts, 1996, p. 5). Similarly, of this "radical document" Cumming stated "the standard was instrumental in raising the profile of records management" (Cumming, 2003). Of AS4390's successor, ISO 15489, Healy (2001, p. 140) said "[it] can be used to improve the image and status of records management in the eyes of those who know little or nothing of the subject. In an American context Gable described DoD 5015.2 as "a tangible contribution in a field generally hungry for guidance" (Gable, 2002).

These statements reveal how recordkeeping standards are viewed by most authors as providing them with tools that standardise previously vague concepts and procedures, and add credibility to the image of their profession. However, for all the obvious enthusiasm as to what these standards mean to the profession there is a tendency towards a lack of research into their utilisation. There is also very little mention of possible draw backs or disadvantages of standard implementation. What research is available is discussed in the following sections.

\subsection{THE ISO 9000 SERIES}

This series of standards have been the subject of much research because of their applicability to numerous industries and influence on many professions. The majority of this research focuses on motivations for obtaining ISO 9000 certification (utilisation) and the advantages or disadvantages of being certified (perceived value) and has taken place in Europe, the United Kingdom and the United States.

The research done by Carlsson and Carlsson (1996) into the implementation of the ISO 9000 series in Swedish industry surveyed 93 companies and revealed that implementation is a highly involved change management process and that the support 
and commitment of top management is essential to mould the culture of an organisation to achieve compliance. Several other studies focus on the advantages or disadvantages of certification. Singels, Ruel and van der Water (2001) concluded from their survey of 192 Dutch organisations that certification does not necessarily lead to improved business performance because many businesses pursue certification out of external pressures. This echoes the findings of Dissanayaka, Kumaraswamy, Karim and Marosszeky (2001) and Douglas, Coleman and Oddy (2003) who concluded the main motivator for achieving certification among Hong Kong construction organisations and United Kingdom manufacturers was the pressure of demands from external customers. This is not to say that certification did not have other advantages, but these studies all found that certification did not automatically yield better business performance. Other factors such as daily adherence to quality systems, organisational culture, and management structures all emerged as influencing factors to business performance.

A Botswana case study is one article that approaches this standard from a recordkeeping perspective, and illustrates the practical effects ISO 9000 certification can have on recordkeeping, presenting the results of the efforts of the Botswana Meat Commission to create effective records practices when moving from a decentralised and chaotic records management system to one in line with ISO 9000 (Sebina, 2001). A 2002 Icelandic study also approached certification from a recordkeeping perspective, revealing that the majority of survey participants found that poor recordkeeping systems were the major stumbling block to achieving compliance (Gunnlaugdottir, 2002).

\subsection{ISO 15489}

Although it is the leading international standard for recordkeeping, surprisingly little research has been done into the utilisation and value of ISO 15489, with the majority of literature concentrating on the development and content of the standard. There are a few exceptions in the form of case studies and research articles.

Julie McLeod and Sue Child's studies are the most cited examples of research into ISO 15489. The results of McLeod's 2003 preliminary study into the impact of the standard 
concluded that at that time there was a high level of primarily positive awareness of the standard (McLeod, 2003). This initial research was followed by a longitudinal study of 50 UK organisations over a two year period that assessed the impact of the standard on recordkeeping practices. Although hindered slightly by personnel changes in the organisations surveyed and the resulting decreased response rate towards the end of the study, McLeod and Childs (2005) concluded that the standard had yet to make a significant impact with utilisation varying greatly over organisations. However, although many records professionals had not yet implemented the standard in their organisations, they were for the most part positive about the standard and many were intending to use it. They also concluded that the perceived value of the standard varied significantly depending on the nature of records management in different organisations, with some records managers happy with the content and status of the standards, and some not, however, most were just happy that the standard now existed.

A later survey of records managers in Commonwealth Africa also aimed to assess the impact of ISO 15489 on recordkeeping practices and drew heavily on McLeod and Childs' work. This study surveyed 17 directors of national archives about their knowledge and use, either current or intended, of ISO 15489 and concluded although utilisation was currently minimal, the standard was seen as desirable and represented opportunities to improve practice (Tough, 2004).

There are several case studies concerning the utilisation of ISO 15489 that represent a variety of different situations and environments. Benfell (2002) presents a case study of implementing a corporate records management programme based on ISO 15489 using a functional analysis approach at the UK Debt Management Office. Man (2005) undertook a very similar functional analysis approach based on ISO 15489 at the UK National Patient Safety Agency. White-Dollmann (2004) details the use of ISO 15489 as a records management tool during the merger of two global companies where she concluded it was a viable model for use in such a situation. Xiaomi and Hongyan (2004) took the approach of using the standard as a tool for measuring records management performance in China and concluded the standard was valuable in identifying gaps in records management procedures. Finally, Jamaican records managers Alexander- 
Gooding and Black (2005) presented the progress to date of Jamaica adopting ISO 15489 as their national records management standard.

Although these studies showed immense situational variation, common themes emerge from all regarding the perceived value of ISO 15489. The first is that it is a strong model that enables assessment, design and implementation of records management systems. The second theme is that it is a process-driven standard which allows for functional analysis of organisations. And the third relates to the positivity of the standard's global status. In terms of deficiencies of the standard, commonalities emerge also, with the most prominent being the voluntary nature of the standard, and that the standard excludes archival records.

\subsection{ElECTRONIC RECORDKEEPING STANDARDS}

Although there are a multitude of standards that relate to electronic recordkeeping, three are most frequently discussed in the literature. However, the trend towards lack of research is apparent here also, and is compounded by the de facto nature of most electronic recordkeeping standards and the diverse and evolutionary nature of electronic recordkeeping itself. Few research based studies into the use and perceived value of these standards are available.

The first prominent standard, DoD 5015.2, was initially developed for the US Department of Defence and subsequently became a de facto standard in US government agencies defining mandatory functionality for electronic records management applications. Gable (2002) points out that because this standard was never intended to become an industry standard it has some inherent weaknesses, one of these being its military background, which she argues has affected the privacy considerations of the standard, with classified information practices taking precedence over freedom of information. It could also be suggested that this is one reason little research has been published into the use of the standard.

The second standard prominent in the literature is MoReq (and its successor MoReq2). Initially developed for the European Commission's Interchange of Data between 
Administrations (DIA) initiative, MoReq is a generic specification for systems designed to manage electronic records, and has been the subject of much debate, primarily in terms of its flaws. Cain (2003) suggests that the standard was unlikely to have a significant impact because of its political affiliations, the availability of more user friendly alternatives (such as DoD 5015.2) and its 128 page length. The chair of the forum that developed MoReq2 five years later admitted similar failings, stating that "ease of use is key" to the new version of the standard (Macfarlane, 2006). A 2009 publication about the utilisation of MoReq2, distinctive in the field because of its nature as a research article, surveyed the opinions of different stakeholders as to the value of MoReq2 and found there was still severe criticism regarding the length of the standard and little agreement as to its possible utilisation and effectiveness (Wilhelm, 2009), suggesting Macfarlane's forum did not achieve its aim.

ISO23081: Metadata for Records is the third standard frequently mentioned in the literature, although it has received very little attention compared its sister-standard ISO 15489. ISO23081 summarises the principles involved in defining records metadata, then outlines the requirements recordkeeping metadata needs to satisfy to fulfil the requirements of ISO 15489 (Reed, 2010, p. 2930). It is surprising that little actual research has been done on the use of this standard considering it was designed as a framework and set of principles within which different countries and organisations could define their own guidelines to implement metadata initiatives. Or conversely, this may be the reason why such research has not been done.

A more recent initiative that has yet to make significant waves in the literature is the International Council on Archives (ICA) standard Principles and Functional Requirements for Records in Electronic Office Environments (ICA-Req), first published in 2008. This standard "provides guidelines on identifying and addressing the needs for records, and a set of generic requirements for records management functionality within business systems software" (ICA, 2008). Archives New Zealand's newest standard, the Digital Recordkeeping Standard, released in August 2010, complies with the first module of this ICA-Req. Unfortunately ICA-Req has yet to receive any comment in the literature. 


\subsection{RECORDKEEPING STANDARDS IN NEW ZEALAND}

There is little available literature regarding recordkeeping standards in New Zealand. In one of the only articles on this topic, Michael Hoyle proposed that the New Zealand recordkeeping profession lacked its own strong theoretical traditions, instead showing the influence of Australian thinking, particularly visible in the use of the Australian series system for archival description and the newly introduced continuum theory. However, the government reforms of the 1980s and 1990s created a regulatory environment conducive to establishing standards, and the privatisation and mergers that also took place highlighted the need for better recordkeeping systems. In this pre-Public Records Act New Zealand, the 1996 formation of the Statutory Regulatory Group whose operational boundaries included standard setting under the Archives Act was a radical (and experimental) move (Hoyle, 1999).

Mike Steemson also praises the New Zealand recordkeeping community for being radical and "far ahead of the game" in terms of standard adoption and setting. He portrays New Zealand as being quick to realise the value of ISO 15489, with Archives New Zealand making a deal with the ISO for a licence to distribute free copies of the standard to public sector agencies, and then basing the vernacular, and content, of the PRA on it, effectively "enshrining" ISO 15489 in a New Zealand context. He compares this New Zealand response with the results of McLeod's work, which revealed low levels of utilisation of the standard in United Kingdom agencies, praising the New Zealand reaction to the standard (Steemson, 2008, p. 28-30).

Very little is available concerning Archives New Zealand's standards, with a review of the Storage Standard in 2008 by Frank Fabry providing the only insight to the reaction to the standards. Fabry's response echoes many we have seen in the global recordkeeping community in response to standards, describing it as "an extremely important step" that "will lead to consistency" (Fabry, 2008, p. 97). Together Fabry, Hoyle and Steemson provide a small insight into recordkeeping standards in New Zealand, however, the brevity of available literature in this area in New Zealand speaks volumes for the dire need for more research in this area. 


\subsection{CONCLUSIONS}

From what research is available two principal impressions emerge. Firstly, standards are viewed by recordkeeping professionals as highly desirable tools for instigating effective recordkeeping systems and also to raise awareness of and the status of the profession. Furthermore, the global origins of these studies suggest that this is an internationally applicable view. The second impression is that there is very little criticism of these standards. The enthusiasm in the literature for standards is overwhelming and not many authors even mention possible drawbacks or disadvantages of implementation of recordkeeping standards. Taking these observations into account, this study aimed to at least make a start on rectifying the distinct lack of research into recordkeeping standards in New Zealand and attempts to present both the positive and negative opinions of recordkeeping professionals concerning the recordkeeping standards they deal with. 


\section{RESEARCH DESIGN}

\subsection{RESEARCH PARADIGM}

This research was informed by a post-positivist paradigm. The term post-positivism refers to the position that there is a tangible, structured and objective social reality that could be 'known' through research and discovery, but the human fallibility of subjection will always inhibit us in truly gaining this knowledge. Because of the lack of research into this area, a project that is broad and provides an overview of the utilisation of Archives New Zealand's standards needs a model that allows for generalisations but does not ignore context, making post-positivism a suitable paradigm.

\subsection{Methodology}

The project employed a quantitative research strategy in an attempt to gain an overall picture of the interaction of standards and public sector recordkeepers, keeping with the post-positivist position that we can attempt to know society through research. The broad methodological stance of the project was quasi-experimental, meaning it was concerned with investigating variables without attempting to control them (Bryman, 2008, pp. 143-144). Quasi-experimental research differs from true experimental research where independent variables are deliberately manipulated by researchers in an attempt to disprove hypotheses (Pickard, 2007, p. 108 \& 297).

\subsection{Data Collection}

Survey research was used to collect the data for this project. This was considered the most appropriate method because of its alignment with quantitative research and because as a student project this research was constrained by time and availability of resources, making survey research a convenient and cost-effective method in this situation. The research instrument was an online self-completed questionnaire constructed using Victoria University's survey software from Qualtrics. An online questionnaire presented a simple and economical option for carrying out survey research and was able to be used to effectively reach and receive responses from the target population. The questionnaire comprised of 22 free text and multiple choice questions, some with multiple-indicator attitude measures. Parts of the questionnaire were modelled on the baseline questionnaire from Julie McLeod and Sue Childs project 
"Assessing the impact of ISO 15489: The first international standard for records management" (McLeod \& Childs, 2005). This study is one of the few pieces of significant research investigating use and opinions of ISO 15489 and, although it was on a much larger scale and possessed a longitudinal component, had similar objectives and research questions to this project. See Appendix 1 of this report for a copy of the questionnaire which includes notations indicating which questions were adapted from McLeod and Childs.

\subsection{Research Population and SAMPle}

Recordkeepers from the public sector formed the population for this study. Although those involved in recordkeeping in private organisations are also users of the standards, they are not obligated to comply with the PRA and the standards are discretionary bestpractice guidelines only. To gain a clear picture of the utilisation of the standards by those obligated to use them, private sector recordkeepers were excluded from the study. The sample type is best classified as a convenience sample because the survey was distributed through the NZ Records listserv, an "open and unmoderated listserv intended for all those who have responsibility for, or an interest in, records management, archives and related disciplines in New Zealand" (NZ Records). This method of distribution was a fast and simple option, but it means that the sample size is not able to be verified. The NZ Records listserv at time of the survey distribution had close to 800 members; however these members come from other disciplines apart from records management, are from both the public and private sectors, and include students, so not all would be in the designated population. It is also not know how many of the members actively check and read the submissions to the list serve. The population for the project was clearly stated in the distributing email and information sheet.

\subsection{Pilot Test}

A pilot test was completed on the research instrument to test its validity before it was used on the sample group. Three members of the population group who were known to the researcher as colleagues and fellow students had the research instrument made available to them for completion and were subsequently informally interviewed to gauge opinions regarding the instrument. They were asked for feedback on the 
accessibility, ease of use, appropriateness of language, size and complexity of the questionnaire. The responses of these testers were discarded and they were asked not to complete the questionnaire when it was circulated on the listserv. Some minor changes were made to the questionnaire following the pilot test, including rewriting of questions with vague wording and the editing of the some of the Qualtrics formatting options to allow multiple answers to some questions where required. Despite these changes following the pilot test, some respondents indicated that they were unsure of the meanings of some of the questions in the questionnaire. This suggests that the study would have benefited from a more structured and comprehensive pilot test.

\subsection{Data Analysis}

Victoria University's survey software from Qualtrics was also used to analyse most of the data. This software allows the researcher to create and distribute questionnaires, monitor responses, view results, and download data in raw or report formats. The report functionality was used to export the data in tables, which include the descriptive statistics of percentage, mean, standard deviation and variance. Further analysis was required on the responses from three of the questions that were free text. Manual coding of this non-numeric data was done in Microsoft Excel, which was then used to calculate descriptive statistics from the coded data. Microsoft Excel was also used to create the graphs in this report.

\subsection{Delimitations/Limitations}

Because this project was broad in scope and aimed to provide an overview of the utilisation of the standards, it approached the standards as a group and did not focus on utilisation and value of the standards as individual entities. This means that the level of detail it provides about individual standards is not very comprehensive. However, it is a starting point and could be expanded in further research. See section 5.3 for implications for further research.

The choice of using a convenience sample made distribution of the research instrument fast and simple but it limited participants to those on the NR Records listserv. Additionally, as an anonymous survey relying on participants to read the information sheet and only respond if they were part of the target population, it is possible that the 
results were not all from this population. This means that the participants may not represent a representative sample of the population and that the results may not be generalisable. 


\section{RESUlts}

\subsection{RESPONSE RATE}

An email asking for participants for the survey and containing a link to the survey and a copy of the participant information sheet (see Appendix 2) was distributed on the NZ Records listserv, with two subsequent follow-up emails encouraging responses distributed at weekly intervals. The survey attracted forty seven full responses from which the data these results are derived from was collated. Because the method of distribution means that the sample size is not able to be verified (see section 3.4) it is not possible to calculate a response rate for this study. However, the researcher considers forty-seven responses to be a very good outcome considering low response rates are often considered one of the weaknesses of survey research. ${ }^{1}$

\subsection{UTILISATION OF THE STANDARDS}

Participants were asked which of the standards had been utilised in their organisation. The results indicate that utilisation of the individual standards by public sector recordkeepers is very mixed. As table 2 shows, the most utilised standard was S7: Create and Maintain Recordkeeping Standard, with 43 (91\%) of the participants indicating that standard had been used in their organisation. Conversely, the least utilised standard was S4: Access with only $18(38 \%)$ responding that they had utilised that standards.

\begin{tabular}{|l|c|c|}
\hline Standard & Respondents & Percentage \\
\hline S7: Create and Maintain Recordkeeping & 43 & $91 \%$ \\
\hline S2: Storage & 38 & $81 \%$ \\
\hline S9: Disposal & 35 & $74 \%$ \\
\hline S8: Electronic Recordkeeping Metadata & 29 & $62 \%$ \\
\hline S5: Digital Recordkeeping & 24 & $51 \%$ \\
\hline S6: Digitisation & 22 & $47 \%$ \\
\hline S4: Access & 18 & $38 \%$ \\
\hline
\end{tabular}

Table 2: Standard utilisation in participants' organisations

Although the numbers for utilisation were quite high - the median figure is 29 (62\%) they were even higher concerning recordkeepers' familiarity with the standards. 44 (96\%) of the participants were familiar with the highest utilised standard S7: Create and

\footnotetext{
${ }^{1}$ The questionnaire allowed participants to choose what questions they answered and did not force answers for all questions. Therefore there are different numbers of respondents for different questions.
} 
Maintain Recordkeeping Standard, and although it was the least utilised standard, 33 (72\%) of the participants felt they were familiar with the access standard S4. The following graph provides a visual comparison of levels of familiarity and levels of utilisation.

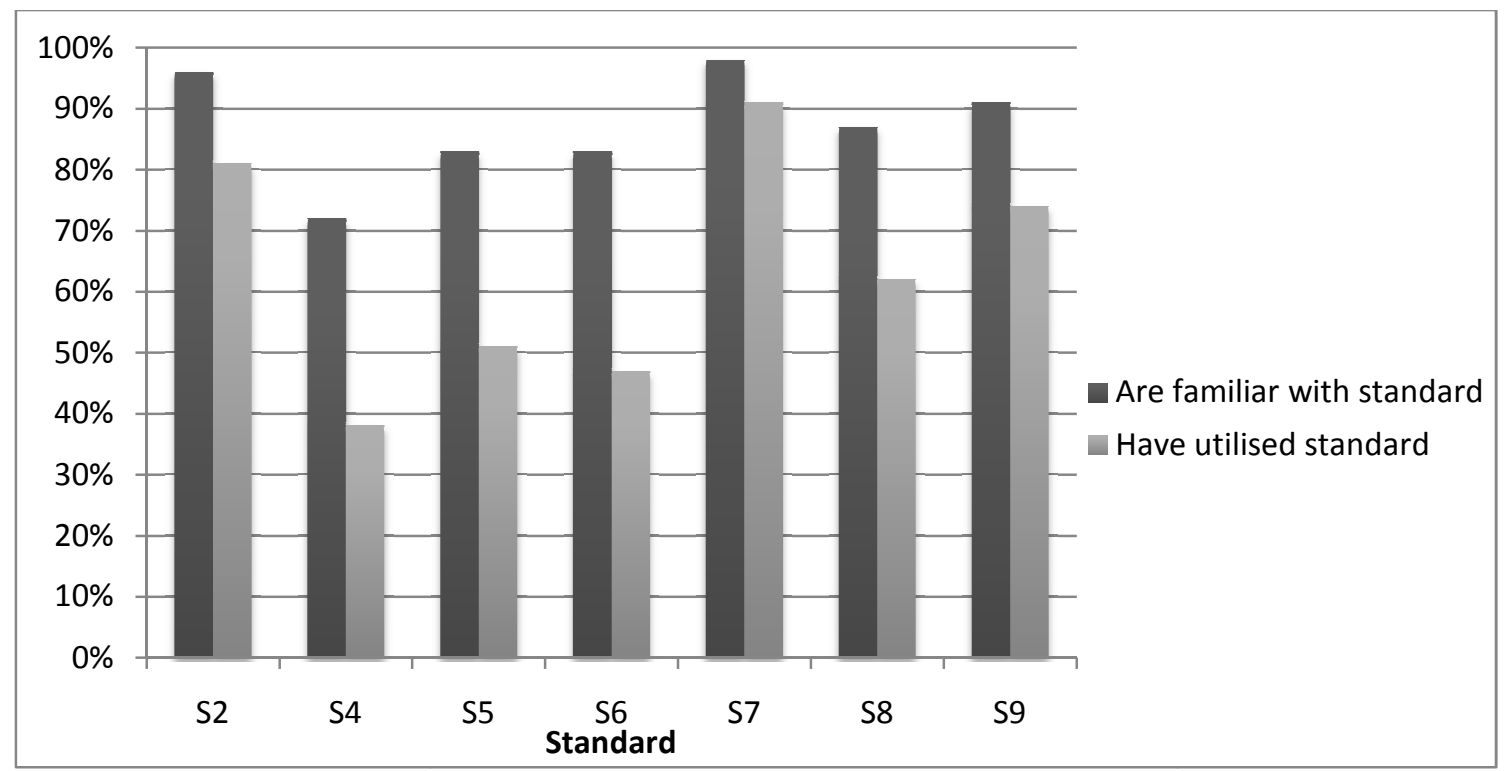

Graph 1: Familiarity with and utilisation of the standards

When considering the status of the standards, the results indicate that the mandatory natures of standards S2: Storage, S7: Create and Maintain Recordkeeping, S8: Electronic Recordkeeping Metadata and S9: Disposal does influence their utilisation. The lowest scoring of the mandatory standards in terms of utilisation in participants' organisations was S8: Electronic Recordkeeping Metadata with 29 (62\%), however, this number was still significantly higher than the highest of the discretionary standards, S5: Digital Recordkeeping with 24 (51\%). 


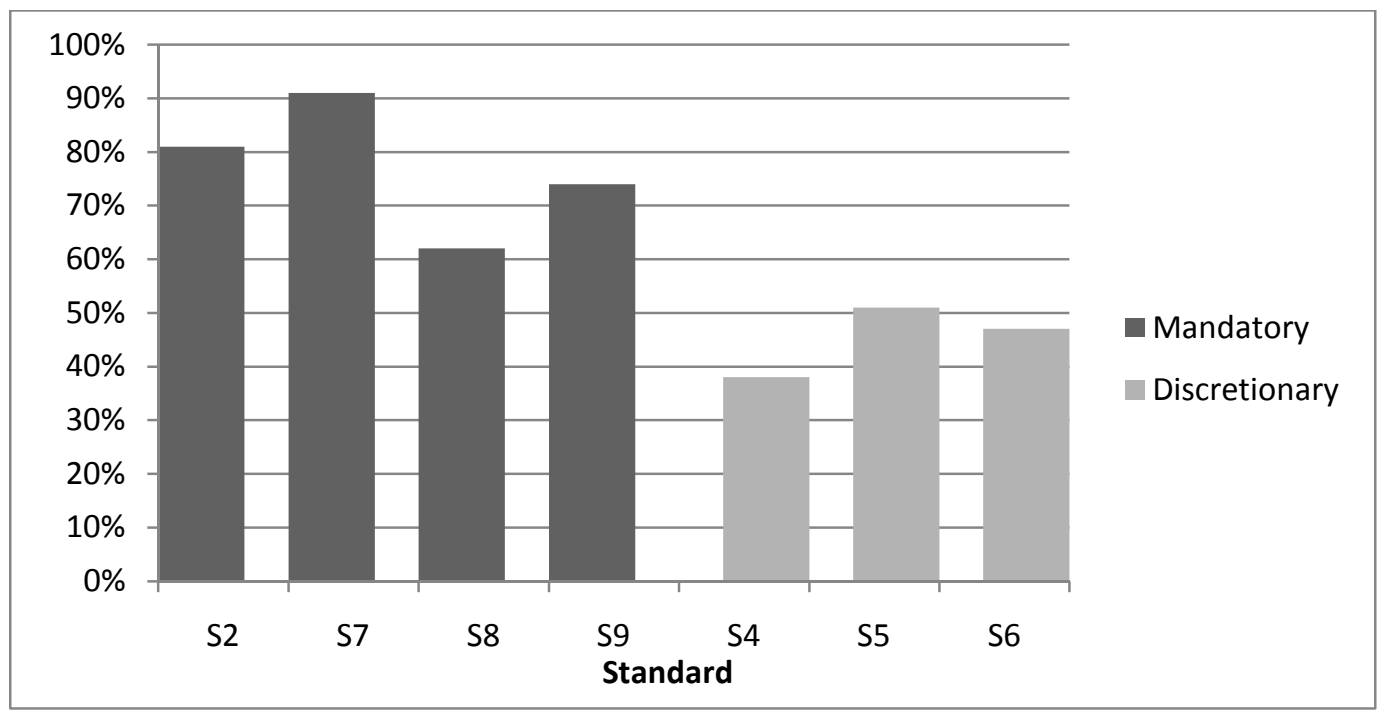

Graph 2: Utilisation of mandatory and discretionary standards

\subsection{The Perceived Value of The STANDards}

Participants were asked to rate the value of the standards in five separate areas. 36 (78\%) of the participants of agreed or strongly agreed that implementing the standards encouraged consistent and/or best records management practice in their organisations, and 32 (70\%) agreed or strongly agreed that implementing the standards helped raised the profile of records management. The standards scored even higher in value when viewed as guides for developing organisational recordkeeping procedures and as tools for auditing current records management practices with $42(95 \%)$ and $40(89 \%)$ of the participants agreeing or strongly agreeing on their value in these areas respectively. The only area where participants did not highly rate the value of the standards is as tools for securing additional resources in organisations. Although $21(46 \%)$ agreed or strongly agreed that they were valuable in this area, 17 (37\%) disagreed or strongly disagreed, the strongest level of disagreement. These results are summarised in table 3 below. 


\begin{tabular}{|l|c|c|c|c|c|c|}
\hline \multicolumn{1}{|c|}{ Area of value in organisation } & \multicolumn{2}{|c|}{$\begin{array}{c}\text { Agree or } \\
\text { strongly agree }\end{array}$} & \multicolumn{2}{c|}{$\begin{array}{c}\text { Disagree or } \\
\text { strongly disagree }\end{array}$} & $\begin{array}{c}\text { No opinion/Not } \\
\text { applicable }\end{array}$ \\
\hline $\begin{array}{l}\text { Developing recordkeeping } \\
\text { procedures }\end{array}$ & 42 & $95 \%$ & 1 & $2 \%$ & 1 & $2 \%$ \\
\hline $\begin{array}{l}\text { Auditing current recordkeeping } \\
\text { practices }\end{array}$ & 40 & $89 \%$ & 2 & $4 \%$ & 3 & $7 \%$ \\
\hline $\begin{array}{l}\text { Encouraging consistent and/or best } \\
\text { records management practice }\end{array}$ & 36 & $78 \%$ & 7 & $15 \%$ & 3 & $7 \%$ \\
\hline $\begin{array}{l}\text { Raising the profile of records } \\
\text { management }\end{array}$ & 32 & $70 \%$ & 5 & $11 \%$ & 9 & $19 \%$ \\
\hline Informing senior managers & 30 & $67 \%$ & 10 & $22 \%$ & 5 & $11 \%$ \\
\hline Securing additional resources & 21 & $46 \%$ & 17 & $37 \%$ & 8 & $17 \%$ \\
\hline
\end{tabular}

Table 3: Perceived value of the standards

Participants were also asked to rate the impact utilisation of the standards had had on their organisation. 27 (59\%) of the participants rated this impact to be of medium level or above, more than the $19(41 \%)$ that rated the organisational impact as low. No participants indicated they felt utilisation of the standards had had no impact on their organisation.

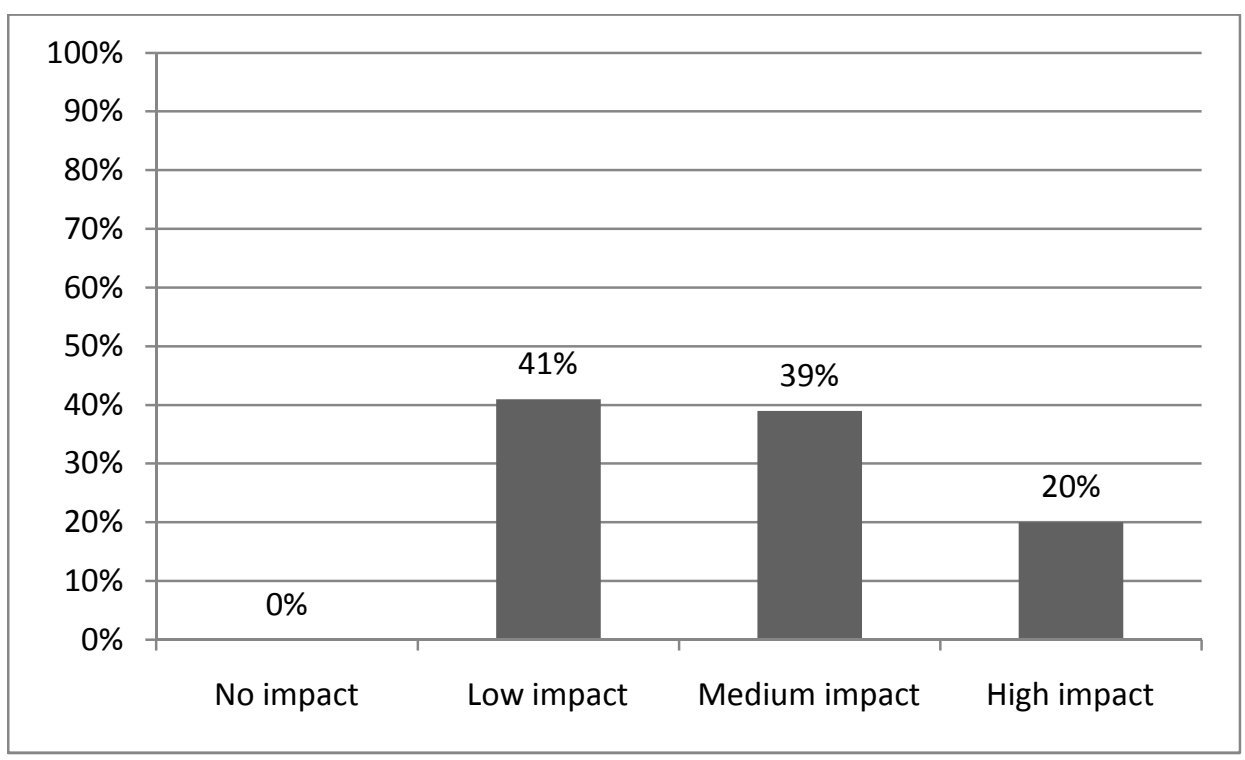

Graph 3: Organisational Impact of Standard Utilisation 


\subsection{UTILISATION DRIVERS AND BARRIERS}

The survey asked participants what their organisations' agendas were that acted as drivers to utilisation of the standards. A number of different drivers were provided in response, with by far the most common one being gaining organisational compliance to the Public Records Act and Archives New Zealand's audit programme. 22 (61\%) of the participants said that this was either the primary driver or at least a significant factor for their organisation in utilisation of the standards. Using the standards as guides for best practice and to inform the development of policies, procedures or and strategies either for recordkeeping or in other organisational areas - were the next most common drivers given.

\begin{tabular}{|l|c|c|}
\hline \multicolumn{1}{|c|}{ Drivers } & \multicolumn{2}{c|}{ Respondents } \\
\hline Compliance with PRA and Audit Programme & 22 & $61 \%$ \\
\hline Best practice & 10 & $28 \%$ \\
\hline Policy/procedure/strategy development & 7 & $25 \%$ \\
\hline Other & 2 & $23 \%$ \\
\hline Accountability & 6 & $14 \%$ \\
\hline Risk management & 5 & $11 \%$ \\
\hline Access to information & 4 & $11 \%$ \\
\hline Preservation for historical/cultural reasons & 4 & $11 \%$ \\
\hline Efficiency & 4 & $8 \%$ \\
\hline Business continuity and performance & 3 & $8 \%$ \\
\hline EDRMS implementation and maintenance & 3 & $6 \%$ \\
\hline Data and metadata management & 2 & $6 \%$ \\
\hline Digitisation projects & 2 & $6 \%$ \\
\hline Internal auditing & 2 & $6 \%$ \\
\hline
\end{tabular}

Table 4: Organisational drivers for standard utilisation

Participants were also asked what their organisations' agendas were that acted as barriers to utilisation of the standards. There was higher commonality between the responses for this question and no singular barrier to utilisation that stood out as a primary reason. Most of the barriers mentioned are not organisational agendas but everyday constraints that the participants view as important barriers to standard utilisation. The highest mentioned barrier was a lack of resources - monetary, staff or time - with $8(42 \%)$ of the participants stating this was a barrier to their organisational utilisation of the standards. A low recordkeeping profile and little organisational

${ }^{2}$ The other category included: quality control, managing the cost of record administration, achieving organisational buy-in, intranet/internet recordkeeping responsibilities, storage needs, and the need for retention and disposal decisions. 
awareness of recordkeeping responsibilities also rated highly, as did competing business priorities and lack of business commitment, and lack of senior management support.

\begin{tabular}{|l|c|c|}
\hline \multicolumn{1}{|c|}{ Barriers } & \multicolumn{2}{c|}{ Respondents } \\
\hline Lack of resources & 8 & $42 \%$ \\
\hline Low profile / Little awareness of recordkeeping responsibilities & 7 & $37 \%$ \\
\hline Competing business priorities/Lack of commitment from business & 6 & $32 \%$ \\
\hline Lack of senior management support & 4 & $21 \%$ \\
\hline Siloed organisational structures and project management & 2 & $11 \%$ \\
\hline The standards themselves / Lack of Archives New Zealand engagement & 2 & $11 \%$ \\
\hline Other standards taking priority & 1 & $5 \%$ \\
\hline
\end{tabular}

Table 5: Organisational barriers to standard utilisation

Another question asked participants that had never utilised any of Archives New

Zealand's standards in their organisation the reasons for this. Competing organisational priorities was the most cited reason among this smaller group of participants.

\begin{tabular}{|l|c|l|}
\hline \multicolumn{3}{|c|}{ Reasons for Not Using the Standards } \\
\hline Competing priorities & 4 & $80 \%$ \\
\hline Lack of resources & 2 & $40 \%$ \\
\hline Organisational culture & 2 & $40 \%$ \\
\hline The content of the standards & 1 & $20 \%$ \\
\hline Organisational change & 1 & $20 \%$ \\
\hline Lack of awareness of existence of the standards & 1 & $20 \%$ \\
\hline
\end{tabular}

Table 6: Reasons given for not utilising the standards in organisations

\subsection{USE OF THE STANDARDS}

The participants were asked what of the following options best described the utilisation of the standards in their organisations:

a. A starting point for records management

b. A risk assessment tool

c. A guide for best practice

d. A basis to develop or review records management policy

e. A basis to develop or review records management procedures

f. To inform senior managers

g. Other 
The findings show the standards were being used by recordkeepers as multipurpose tools with 31 of 46 participants (67\%) indicating they used the standards for four or more different purposes. Using the standards as guides for best practice was the most common reason cited, with use as a basis to develop or review records management procedures next common. The least cited reason was to use the standards to inform senior managers.

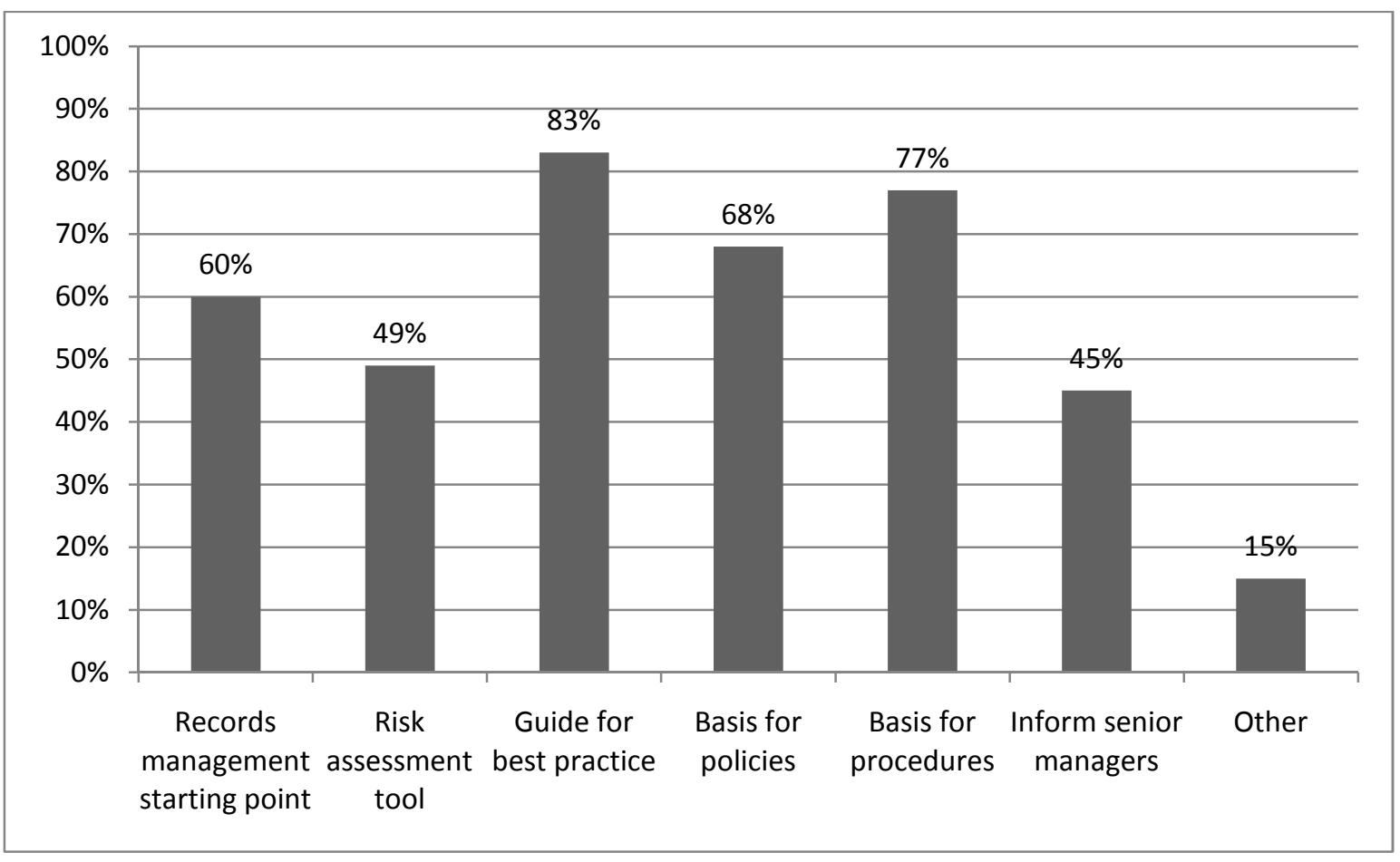

Graph 4: How the standards are being used by recordkeepers

A common "other" reason cited by participants is that the standards were being used to assist with the implementation of Electronic Document and Records Management Systems (EDRMS) in their organisations. Another specified use was the standards were being used to help achieve organisational buy-in for specific actions and activities.

\subsection{COMPARISON TO OPINIONS ABOUT ISO 15489}

As discussed in the literature review, author opinions about the international standard for records management ISO 15489 are overwhelmingly positive. That there are very few negative opinions in the literature is a notable feature. Key themes about ISO 15489 in the literature include:

- The standard is highly welcome to a profession desiring guidance 
- It standardises concepts and procedures that were previously vague

- It has the ability to improve the image and status of records management as a profession

- The discretionary nature of the standard is criticised by some who feel it should be a compliance standard

The opinions expressed in this study differ considerably to those in the literature concerning ISO 15489 in the fact that many negative opinions were expressed in addition to positive ones. Although, like ISO 15489, many participants felt the standards were good to have, they also said the standards were "unachievable", "unrealistic" and lack "practical advice about how to implement them". The opinions in this study are also considerably different because of the large variation in opinions across the respondent group. Unlike the predominantly positive voices in the literature concerning ISO 15489 , the participants in this study have a multitude of conflicting opinions about the content, style and application of the standards. Table 7 illustrates some of these opinions.

\begin{tabular}{|l|l|}
\hline Overly wordy & Clear, concise \\
\hline Well written & Written for a specialist audience \\
\hline $\begin{array}{l}\text { All the standards need to be } \\
\text { mandatory }\end{array}$ & $\begin{array}{l}\text { The discretionary standards shouldn't } \\
\text { be made mandatory }\end{array}$ \\
\hline Well prepared & Too prescriptive \\
\hline
\end{tabular}

Table 7: Conflicting opinions about the Standards 


\section{DisCUSSION}

\subsection{RESEARCH QUESTIONS}

How extensive is usage of Archives New Zealand's recordkeeping standards?

Archives New Zealand's recordkeeping standards are being utilised in the organisations of many public sector recordkeepers. Most of the participants in this project indicated that at least one of the standards had been used in their organisation and many said several of them had been utilised. In total, five of the seven standards had been utilised in more than half of the respondents' organisations. Although the mandatory standards are being used more, the discretionary standards are also being used, and all are being utilised in many different ways and for a variety of reasons.

To what extent are these standards perceived as valuable recordkeeping tools among public sector recordkeepers?

Overall, public sector recordkeepers do deem the standards (as a holistic group) to be valuable resources. They are considered most valuable to assist in developing recordkeeping procedures and with auditing current recordkeeping practices, however, they are being utilised most as guides for best practice. This suggests that this is an area where recordkeepers desire the most assistance but they do not feel that the standards are necessarily that valuable, with the participants' ratings of their value as guides for best practice placing this aspect third out of the six they were questioned on. Comments received from participants suggest the reason for this to be the style and content of the standards, not the concepts they represent. "The standards are overly wordy and are viewed as too prescriptive by my organisation", commented one participant. Another remarked that "I think many of the standards are unachievable given the level of expertise required", and a third noted variations between all the standards, saying that "some standards are better written than others in terms of the way that concepts are introduced and then logically developed". Finally, a participant noted that "I think Archives New Zealand too often provides rules/standards but no practical advice about how to implement them". Despite these concerns about the style and content of the standards, they are valued as guidance in an area where many are finding obstacles and 
barriers widespread. The fact that the standards - both mandatory and discretionary are being used in multiple organisations attests to this.

What drivers and/or barriers exist that affect the utilisation of the standards? Compliance to the Public Records Act and recognition that Archives New Zealand's audit programme is underway is the number one driver for utilisation and the mandatory standards are being utilised considerably more than those with a discretionary status. Although one participant was of the opinion that "no one cares if it is not a compulsory standard", several commented that the fact that some of the standards are mandatory under the PRA is not sufficient in itself to make their organisations commit to change. "They don't care that they aren't compliant...they don't want to become compliant...and I am seen as the person standing in their way of doing what they want to do", commented one participant, while another said that their organisation has a "willingness to accept penalties for non-compliance".

The barriers to standard utilisation displayed considerable commonalities, with a lack of resources, low awareness or basic disinterest of recordkeeping responsibilities in organisations, lack of commitment from the organisation to these responsibilities and competing business priorities emerging as common barriers throughout the respondents' organisations.

How are public sector recordkeepers using the standards?

Although compliance to the Public Records Act is the most common reason as to why the standards are being utilised, they are being used in multiple ways with $67 \%$ of participants indicating they used the standards for four or more different purposes within their organisation. The most common uses are as guides for best practice and as a basis from which to develop or review records management policies or procedures. 
How do public sector recordkeepers' opinions concerning the standards compare to opinions voiced in the literature regarding ISO 15489?

Unlike the overwhelmingly positive opinions expressed in the literature about ISO 15489 , there is considerable variation of opinion among public sector recordkeepers on the issue of these standards. The negative comments noted above (page 26) regarding the content and style of the standards hold little similarity to opinions in the literature about ISO 15489, and the fact many participants were also positive about the standards themselves but emphasised other various areas of concern illustrates the varied and often conflicting range of opinions among the survey participants. One said "[it is] good to have the standards but I think there is too much overhead in creating/reviewing them given the size of Archives New Zealand and the similarity of the content to standards in other jurisdictions. I'd go for a joint Australia/New Zealand [approach]". Others emphasised organisational barriers with one commenting that the "standards are well prepared but it depends if an organisation carries [them] out or not" and another that "the PRA and the standards represent a huge change in the way we think about managing information". Overall, the opinions of public sector recordkeepers in New Zealand of the standards with which they work bear little resemblance to the predominantly academic opinions that praised the value of ISO 15489 to the recordkeeping profession. The varied nature of the opinions collected in this study suggests an area for further research, discussed in section 5.3 below.

\subsection{STANDARDS AS DIFFUSIONS OF INNOVATIONS}

Roger's Diffusion of Innovations theory was used as a framework to explore the utilisation of Archives New Zealand's standards by approaching the standards as new innovations or ideas, and viewing users of the standards as adopters of innovations. Although the goal of the study was not to test Rogers' theory, some comparisons can be made between Rogers' ideas and the results. The commonalities that emerged in this study, such as the common barriers to standard utilisation and value placed on recordkeeping guidance and assistance, illustrate how Rogers' definition of a social system - interrelated units solving problems with a common objective (Rogers, 2003, p. 23) - can be applied to the community of public sector records professionals. Responses received from participants indicate that the attributes of compatibility and complexity 
are important when considering adoption of the standards. Further research into this area could investigate this decision making process and map results to Rogers' attributes as well as looking at the relationship between standard adoptions over time and categorising adopters into the five stages of innovativeness. The mandatory status of some of the standards would have to be considered for such research because of the strength of compliance as a driver. 


\section{CONCLUSIONS AND IMPLICATIONS FOR FUTURE RESEARCH}

The aim of the study was to reveal how widespread utilisation of Archives New Zealand's recordkeeping standards is and how valuable public sector recordkeepers believe the standards are. The results suggest that the standards are being used throughout many organisations for many different reasons and that their presence is mostly valued by those records management professionals charged with achieving their organisations' compliance with the PRA. The wealth of various opinions concerning the standards that came through in this study indicates that Archives New Zealand would gain much valuable feedback from research into the opinions of the people using their standards. Investigating the style and content of the standards in particular could reveal some interesting results because, although the respondents in this study were not asked directly about these aspects, there were many comments made concerning them and this was where the results were most conflicting.

Because the project was broad and attempted to provide an overview of Archives New Zealand's standards as a whole, it did not investigate each standard as an individual tool. Further study into the utilisation and value of each individual standard could expand on these findings and reveal more detail about how individual standards are being used and for what purposes, and well as ascertaining what standards users find most valuable and why. Separating mandatory and discretionary standards into two areas of research would be useful because the drive to comply with the PRA through observing the requirements of these standards comes through very strongly in the results and has the ability to obscure less obvious findings. The varied and sometime conflicting opinions of the participants suggest that they may come from various backgrounds and have various levels of experience in recordkeeping. Research that provides more illumination about the target audience of the standards could yield useful results that may assist those who compose these standards.

The high level of response and positive comments received from colleagues, participants and others within the records management profession about this research projects suggests that public sector recordkeepers in New Zealand desire more research to be done in their area of work and expertise and would be keen to assist with future research. 


\section{BIBLIOGRAPHY}

Alexander-Gooding, S. \& Black, S. (2005). A national response to ISO 15489: A case study of the Jamaican experience. Information Management Journal, 39 (2), 62-66.

Archives New Zealand. (n.d.). Recordkeeping Publications. Retrieved August 16, 2010, from http://continuum.archives.govt.nz/recordkeeping-publications.html

Benfell, P. (2002). An integrated approach to managing electronic records. Records Management Journal, 12 (3), 94-97.

Brumm, E. (1996). The marriage of quality standards and records management. Records Management Quarterly, 30 (2), 3-10.

Bryman, A. (2008). Social research methods, 3rd edition. New York: Oxford University Press.

Cain, P. (2003). MoReq: The standard of the future? Information Management Journal, 37 (2), 54-59.

Carlsson, M. \& Carlsson, D. (1996). Experiences of implementing ISO 9000 in Swedish industry. International Journal of Quality \& Reliability Management, 36-47.

Cumming, K. (2003). Evolution and requirements of ISO 15489. Retrieved July 23, 2010, from Archives New Zealand: http://archives.govt.nz/sites/default/files/katec-03-10.pdf

Dissanayaka, S., Kumaraswamy, M., Karim, K. \& Marosszeky, M. (2001). Evaluating outcomes from ISO 9000- certified quality systems of Hong Kong constructors. Total Quality Management, 12 (1), 29-40.

Douglas, A., Coleman, S. \& Oddy, R. (2003). Perspective: The case for ISO 9000. The TQM Magazine, 15 (5), 316-324.

Fabry, F. (2008). Book review - Storage standard: Standard for the storage of records and archives. Archifacts, 97-99.

Gable, J. (2002). Everything you wanted to know about DoD 5015.2. Information Management Journal, 36 (6), 32-38.

Gunnlaugdottir, J. (2002). The quality must be on record: a survey of organisations having an ISO 9000certification in Iceland. Records Management Journal, 12 (2), 40-47.

Healy, S. (2001). ISO 15489 Records Management - its development and significance. Records Management Journal, 11 (3), 133-142.

Hofman, H. (2006). Standards: not "one size fits all". Information Management Journal, 40 (3), 36-45.

Hoyle, M. (1999). Review, restructure, and reform: Recordkeeping standards in the New Zealand state sector. Archivaria, 48, 44-63.

International Council on Archives. (2008). Principles and Functional Requirements for Records in Electronic Office Environments - Module 3: Guidelines and Functional 
Requirements for Records in Business Systems. Retrieved June 4, 2011, from http://www.archives.qld.gov.au/downloads/guidelines_functional_requirements.pdf International Organisation for Standardization. (2011). ISO 9000: Quality Management. Retrieved June 4, 2011, from http://www.iso.org/iso/iso_catalogue/management_and_leadership_standards/quality _management.htm

Jones, V. A. (2003). Protecting records: What the standards tell us. The Information Management Journal, 70-75.

Macfarlane, I. (2006). Managing electronic records: Standards and their use in practice. European Conference on Archives, May 18-20 2006, Warsaw. Available at: http://archiwa.gov.pl/repository/wz/VII\%20Konferencja/Papers/I_Macfarlane_Managin g\%20Electronic\%20Records_Standards.pdf.

Man, E. (2005). A functional approach to appraisal and retention scheduling. Records Management Journal, 15 (1), 21-33.

McLeod, J. (2003). Assessing the impact of ISO 15489 - a preliminary investigation. Records Management Journal, 70-82.

McLeod, J., \& Childs, S. (2005). Assessing the impact of ISO 15489 - the first international standard for records management: Final project report. Newcastle upon Tyne: Information Society Research \& Consultancy Group, Northumbria University. Retrieved May 31, 2011 from http://www.northumbria.ac.uk/static/5007/ceispdf/isorep.pdf

Naveh, E., \& Marcus, A. (2005). Achieving competitive advantage through implementing a replicable management standard: Installing and using ISO 9000. Journal of Operations Management, 24, 1-26.

NZ Records. (n.d.). NZ Records Info Page. Retrieved January 15, 2011, from http://lists.vuw.ac.nz/mailman/listinfo/nzrecords

Pember, M. (2006). Sorting out the standards: What every records and information professional should know. Records Management Journal, 21-33.

Pickard, A. J. (2007). Research Methods in Information. London: Facet.

Punch, K. (1998). Introduction to social research: Quantitative and qualitative approaches. London: Sage.

Reed, B. (2010). International Records Management Standards ISO 15489 and 23081. In Encyclopedia of Library and Information Sciences, 3rd edition (pp. 2928-2933).

Rogers, E. (2003). Diffusion of innovations, 5th edition. New York: Free Press.

Sebina, P. M. (2001). ISO standards and records management: The case of the Botswana Meat Commission. African Journal of Library, Archives and Information Science, 11 (1), 49-59. 
Singels, J., Ruel, G., \& van der Water, H. (2001). ISO 9000 series: certification and performance. International Journal of Quality \& Reliability Management, 18 (1), 62-75.

Stephens, D. (1996). ISO 9000 and international records management. Records Management Quarterly, 30 (3), 67-72.

Stephens, D. (2000). International standards and best practices in RIM. The Information Management Journal, 68-71.

Steemson, M. (2006). We're not all stumbling towards the standard: The 'create and maintain' impact of ISO 15489. InfoRMAA Quarterly, 24 (1), 28-30.

Stephens, D. O., \& Roberts, D. (1996). From Australia: The world's first national standard for records management. Records Management Quarterly, 30 (4), 3-9.

Tough, A. (2004). Records management standards and the good governance agenda in Commonwealth Africa. Archives \& Manuscripts, 32 (2), 142-161.

White-Dollmann, M. M. (2004). ISO 15489: A tool for records management mergers. Information Management Journal, 38 (5), 39-44.

Wilhelm, P. (2009). A evaluation of MoReq2 in the context of national EDRMS standard developments in the UK and Europe. Records Management Journal, 117-133.

Wise, C., \& Stamoolis, P. (1993). ISO 9000: An opportunity of records management professionals. Records Management Quarterly, 27 (4), 3-11.

Wright, S. (1979). Quantitative methods and statistics. London: Sage.

Xiaomi, A., \& Hongyan, J. (2004). Assessing records management in China against ISO 15489 and the implications. Records Management Journal, 14 (1), 33-39. 


\section{APPENDices}

\section{APPENDiX 1: STUdy QUeSTIONNAIRE}

This is a text version of the online questionnaire that was made available to participants through the survey software, Qualtrics. The questionnaire contains a mixture of new questions developed by the researcher and questions adapted from the baseline questionnaire from McLeod and Childs' project Assessing the impact of ISO 15489: The first international standard for records management (McLeod \& Childs, 2005, pp.29-31). The adapted questions are identified by as asterisk $\left({ }^{*}\right)$ at the end of the question.

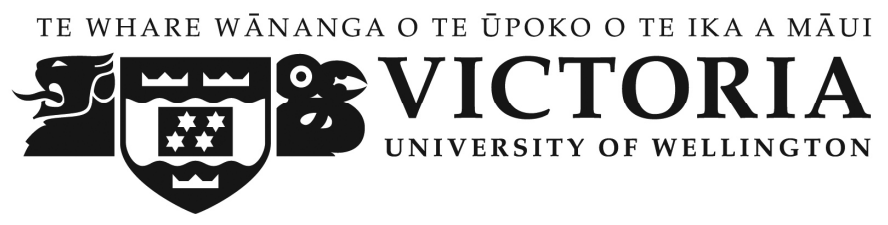

1. What is your current job title?

2. What is the size of your organisation (employee numbers)?
a. Less than 50
b. $50-99$
c. $100-299$
d. $300-499$
e. More than 500

3. How long have you been involved in the field of records management?
a. Less than 3 months
b. 3 - 9 months
c. 9 - 18 months
d. 18 months -3 years
e. 4 - 6 years
f. More than 6 years

4. How many people have principal responsibility for records management in your organisation? *
a. None
b. 1 person
c. 2 - 5 people
d. 6 - 10 people 
e. More than 10 people

5. There is a formal records management policy in your organisation. *
a. True
b. False
c. Unsure

6. There are formal records management procedures in your organisation. *
a. True
b. False
c. Unsure

7. Please indicate which of the following Archives New Zealand standards you are familiar with. Please choose all that apply.
a. S2: Storage Standard
b. S4: Access Standard
c. S5: Digital Recordkeeping Standard
d. S6: Digitisation Standard
e. S7: Create and Maintain Recordkeeping Standard
f. S8: Electronic Recordkeeping Metadata Standard
g. S9: Disposal Standard
h. None of the above

8. Please indicate which of the following Archives New Zealand standards have been utilised by your organisation. Please choose all that apply.
a. S2: Storage Standard
b. S4: Access Standard
c. S5: Digital Recordkeeping Standard
d. S6: Digitisation Standard
e. S7: Create and Maintain Recordkeeping Standard
f. S8: Electronic Recordkeeping Metadata Standard
g. S9: Disposal Standard
h. None of the above

9. What option(s) best describe this utilisation? Please choose all that apply. *
a. A starting point for records management
b. A risk assessment tool
c. A guide for best practice
d. A basis to develop or review records management policy
e. A basis to develop or review records management procedures
f. To inform senior managers
g. Other, please explain: 
h. Not applicable in my organisation

10. What are your organisation's agendas that act as drivers to the utilisation of the standards? ${ }^{*}$

11. What has been the impact of this utilisation been on your organisation? *
a. No impact
b. Low impact
c. Medium impact
d. High impact
e. None of the Archives New Zealand standards have been utilised by my organisation

12. Please indicate the sources through which you have been informed of the Archives New Zealand standards. Please choose all that apply.
a. Archives New Zealand published materials
b. Archives New Zealand website
c. Archives New Zealand recordkeeping forums
d. Word of mouth
e. Professional development/study
f. Other, please explain:
g. I do not know of these standards

13. If your organisation has NEVER utilised any of the standards, what are the main reasons for this? Please choose all that apply. *
a. The content of the standards themselves
b. Organisational culture
c. Organisational change
d. Lack of resources
e. Competing priorities
f. Lack of awareness of the existence of the standards
g. Other, please explain:
h. Not applicable in my organisation

14. What are your organisation's agendas that act as barriers to the utilisation of the standards? *

15. That discretionary standards S4, S5, S6 and S8 are NOT compliance standards is a disadvantage towards their utilisation in my organisation. *
a. Strongly agree
b. Agree
C. Disagree
d. Strongly disagree
e. No opinion
f. I do not know of these standards 
16. Standards are NOT important in my organisation. *
a. Strongly agree
b. Agree
c. Disagree
d. Strongly disagree
e. No opinion

17. Implementing the standards helped raise the profile of records management in my organisation. *
a. Strongly agree
b. Agree
c. Disagree
d. Strongly disagree
e. No opinion
f. I do not know of these standards
g. Not applicable in my organisation

18. Implementing Archives New Zealand's standards encouraged consistent/best records management practice in my organisation. *
a. Strongly agree
b. Agree
c. Disagree
d. Strongly disagree
e. No opinion
f. I do not know of these standards
g. Not applicable in my organisation

19. Archives New Zealand's standards have been useful to inform senior managers in my organisation. *
a. Strongly agree
b. Agree
c. Disagree
d. Strongly disagree
e. No opinion
f. I do not know of these standards
g. Not applicable in my organisation

20. Archives New Zealand's standards have been useful for auditing current records management practice in my organisation. *
a. Strongly agree
b. Agree
c. Disagree
d. Strongly disagree 

e. No opinion
f. I do not know of these standards
g. Not applicable in my organisation

21. Archives New Zealand's standards are useful for as guides for developing organisation recordkeeping procedures. *
a. Strongly agree
b. Agree
c. Disagree
d. Strongly disagree
e. No opinion
f. I do not know of these standards
g. Not applicable in my organisation

22. Archives New Zealand's standards are useful for as tools to secure additional resources in my organisation. *
a. Strongly agree
b. Agree
c. Disagree
d. Strongly disagree
e. No opinion
f. I do not know of these standards
g. Not applicable in my organisation

23. Do you have any additional comments relating to the standards? 


\title{
APPENDix 2: PARTICIPANT INFORMATION SHEET
}

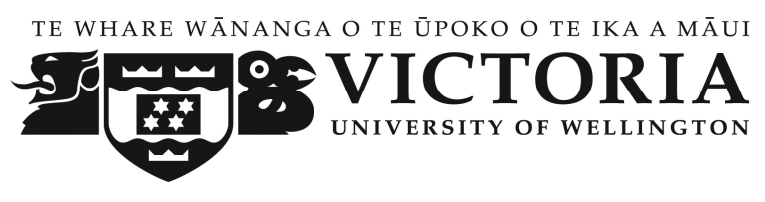

\section{Participant Information Sheet}

\author{
Researcher: Grace Currie, \\ School of Information Management, \\ Victoria University of Wellington
}

\begin{abstract}
I am a Master of Information Studies student at Victoria University of Wellington and am undertaking a research project as part of my degree. The aim of my project is to investigate the utilisation and perceived value of the recordkeeping standards issued by Archives New Zealand, Department of Internal Affairs, from the point of view of recordkeepers from public sector organisations.
\end{abstract}

I am inviting participants who are involved in public sector records management to partake in answering a simple, online questionnaire, which will take approximately 5-10 minutes to complete. Participation is entirely voluntary and anonymous. Completion of the questionnaire implies consent to take part in the study. Two follow-up invitations will be sent to remind possible participants to complete the questionnaire, one after seven days and one after fourteen days.

Victoria University of Wellington requires that ethics approval be obtained for all research involving human participants, prior to the beginning of this data collection stage. The anonymous responses received will constitute the basic data for my research project and the results will be transformed into a written report which will later form the basis of an article for publication in a academic/professional journal and/or dissemination at an academic/professional conference. It will not be possible to identify the participants of the study personally. All material collected throughout the course of the project will be stored in a password protected file and will be restricted to myself, the researcher, and my supervisor, Dr Gillian Oliver. All respondent questionnaires will be destroyed one year after the conclusion of the research.

I invite you to send me an email at curriegrace@myvuw.ac.nz if you would like to receive a summary of the results post-completion of the project.

If you have any questions or would like to receive further information about the project please contact me on curriegrace@myvuw.ac.nz or (04) 931 4642, or my supervisor Dr Gillian Oliver, Senior Lecturer at the School of Information Management, on gillian.oliver@vuw.ac.nz or (04) 4637437.

Thank you for taking time to read this information sheet and I invite you to please complete the questionnaire. 


\section{APPENDix 3: RaW Data SAMPle \\ This is a raw data sample, in XML format, of five of the survey responses.}

$<$ xml $><$ Response $><$ ResponseID $>$ R_cIQhBsow1r7kQ9C $</$ ResponseID $><$ ResponseSet $>$ Defau lt Response

Set $</$ ResponseSet $><$ Name $>$ Anonymous $</$ Name $><$ ExternalDataReference $></$ ExternalDat aReference $><$ EmailAddress $></$ EmailAddress $><$ IPAddress $>130.195 .91 .142</$ IPAddres $\mathrm{s}><$ Status $>0</$ Status $><$ StartDate $>2011-03-11$

$11: 57: 52</$ StartDate $><$ EndDate $>2011-03-11$

12:04:01</EndDate $><$ Finished $>1</$ Finished $><$ Q $1>$ Manager Record Services $</ Q 1><Q 2>5</ Q 2><Q 3>5</ Q 3><Q 4>2</ Q 4><Q 5>1</ Q 5><Q 6>1</ Q 6><07 \_1>1</ Q 7$

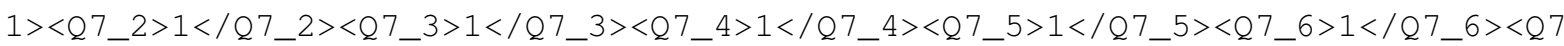
_ $7>1</ 07 \_7><07 \_8></ 07 \_8><09 \_1>1</ 09 \_1><09 \_2></ 09 \_2><09 \_3>1</ 09 \_3><09 \_4></ 09$ _4 $><09 \_5>1</ 09 \_5><09 \_6>1</ 09 \_6><09 \_7>1</ 09 \_7><09 \_8></ 09 \_8><Q 8 \_1>1</ 08 \_1><08$

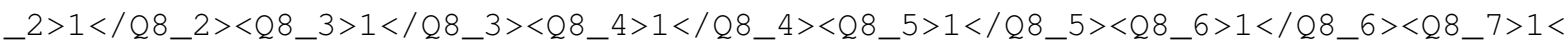
/Q8_7 $><Q 8 \_7 \_T E X T><$ ! [CDATA [Self assessment audits from peformance management/reporting perspective] ] $></ Q 8$ 7_TEXT $><Q 8$ Q $8></ Q 8 \_8><Q 10><$ ! [CDATA [Combination of Improved efficiency / Improved accountability / Improved best practive / Reduced risk / Compliance. Compliance probably being greatest driver at present ] ] $></ \mathrm{Q} 10><\mathrm{Q} 11>3</ \mathrm{Q} 11><\mathrm{Q} 12 \_1>1</ \mathrm{Q} 12 \_1><\mathrm{Q} 12$ _2 $>1</ \mathrm{Q} 12 \_2><\mathrm{Q} 12 \_3>1</ \mathrm{Q} 12$ _3 $><Q 12 \_4></ Q 12 \_4><Q 12 \_5>1</ Q 12 \_5><Q 12 \_6>1</ Q 12 \_6><Q 12 \_6$ TEXT $>$ I was a member of the working group around the disposal

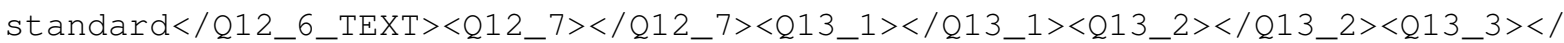

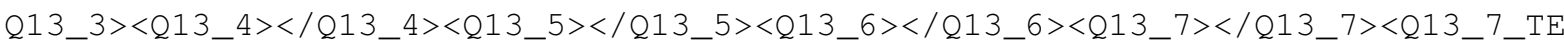
$\left.\mathrm{XT}></ \mathrm{Q} 13 \_7 \_\mathrm{TEXT}\right\rangle\left\langle\mathrm{Q} 13 \_8>1</ \mathrm{Q} 13 \_8><\mathrm{Q} 14\right\rangle\langle$ ! [CDATA [N $\left.\left.\left./ \mathrm{A}]\right]\right\rangle\langle/ \mathrm{Q} 14\rangle\langle\mathrm{Q} 15\rangle 2</ \mathrm{Q} 15\right\rangle\langle\mathrm{Q} 17\rangle$ $3</ \mathrm{Q} 17><\mathrm{Q} 18>2</ \mathrm{Q} 18><\mathrm{Q} 19>2</ \mathrm{Q} 19><\mathrm{Q} 20>2</ \mathrm{Q} 20><\mathrm{Q} 21>1</ \mathrm{Q} 21><\mathrm{Q} 22>1</ \mathrm{Q} 22><\mathrm{Q} 23>2</$ Q23 $><$ Q24 $></$ Q24 $></$ Response $>$

$<$ Response $><$ ResponseID $>$ R_ailbVhzKDWIPiZu</ResponseID $><$ ResponseSet $>$ Default Response

Set $</$ ResponseSet $><$ Name $>$ Anonymous $</$ Name $><$ ExternalDataReference $></$ ExternalDat aReference $><$ EmailAddress $></$ EmailAddress $><$ IPAddress $>203.97 .202 .217</$ IPAddres $\mathrm{s}><$ Status $>0</$ Status $><$ StartDate $>2011-03-11$

$12: 01: 59</$ StartDate $><$ EndDate $>2011-03-11$

$12: 04: 34</$ EndDate $><$ Finished $>1</$ Finished $><$ Q $1>$ Information

Manager $</ \mathrm{Q} 1><\mathrm{Q} 2>2</ \mathrm{Q} 2><\mathrm{Q} 3>6</ \mathrm{Q} 3><\mathrm{Q} 4>3</ \mathrm{Q} 4><\mathrm{Q} 5>1</ \mathrm{Q} 5><\mathrm{Q} 6>2</ \mathrm{Q} 6><\mathrm{Q}$ 7_1 $>1</ \mathrm{Q} 7 \_1$

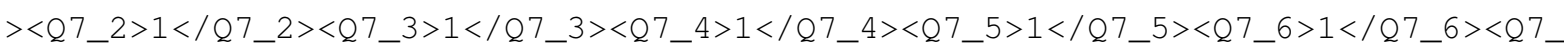
$7>1</ 07 \_7><07 \_8></ 07 \_8><09 \_1>1</ 09 \_1><09 \_2></ 09 \_2><09$ 3 $></ 09 \_3><09 \_4></ 09 \_4$ $><09 \_5>1</ 09 \_5><09 \_6></ 09 \_6><09 \_7></ 09 \_7><09 \_8></ 09 \_8><08 \_1>1</ 08 \_1><08 \_2><$

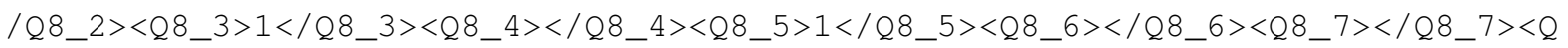

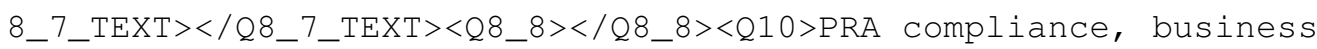
efficiency $</ Q 10><Q 11>2</ Q 11><Q 12 \_1>1</ Q 12 \_1><Q 12 \_2>1</ Q 12 \_2><Q 12 \_3>1</ Q 12 \_3$

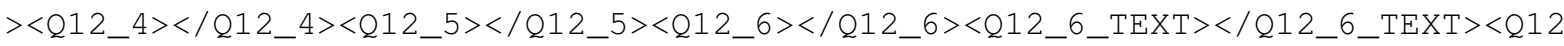
_ $7></ Q 12 \_7><Q 13 \_1></ Q 13 \_1><Q 13 \_2></ Q 13 \_2><Q 13 \_3></ Q 13 \_3><Q 13 \_4></ Q 13 \_4><Q 13$ _5 $></ Q 13 \_5><Q 13 \_6></ Q 13 \_6><Q 13 \_7></ Q 13 \_7><Q 13 \_7$ TEXT $></$ Q13_7_TEXT $><Q 13 \_8>1<$ /Q13_8 $><$ Q14 $>$ Lack of commitment to implementation and amendment of business processes to meet the standards $</ Q 14><Q 15>1</ Q 15><Q 17>1</ Q 17><Q 18>2</ Q 18><Q 19>2</ Q 19><Q 20\rangle 3</ Q 20\rangle$ $<$ Q21 $>2</ \mathrm{Q} 21><\mathrm{Q} 22>1</ \mathrm{Q} 22><\mathrm{Q} 23>3</ \mathrm{Q} 23><\mathrm{Q} 24></ \mathrm{Q} 24></$ Response $>$

$<$ Response $><$ ResponseID $>$ R_ebKNmbo3HPSF5Z2</ResponseID $><$ ResponseSet $>$ DefaultRes ponseSet $</$ ResponseSet $><$ Name $>$ Anonymous $</$ Name $><$ ExternalDataReference $></$ Extern 
alDataReference $><$ EmailAddress $></$ EmailAddress $><$ IPAddress $>202.36 .173 .34</$ IPAd dress $><$ Status $>0</$ Status $><$ StartDate $>2011-03-11$

$12: 06: 56</$ StartDate $><$ EndDate $>2011-03-11$

$12: 10: 00</$ EndDate $><$ Finished $>1</$ Finished $><Q 1>$ Records

ManagementAdvisor $</ \mathrm{Q} 1><\mathrm{Q} 2>4</ \mathrm{Q} 2><\mathrm{Q} 3>6</ \mathrm{Q} 3><\mathrm{Q} 4>3</ \mathrm{Q} 4><\mathrm{Q} 5>1</ \mathrm{Q} 5><\mathrm{Q} 6>1</ \mathrm{Q} 6><\mathrm{Q} 7$ _1 $>1</ Q 7 \_1><Q 7 \_2>1</ Q 7 \_2><Q 7 \_3>1</ Q 7 \_3><Q$ 7_4 $>1</ Q 7 \_4><Q$ 7_5 $>1</ Q 7 \_5><Q 7 \_6>1<$

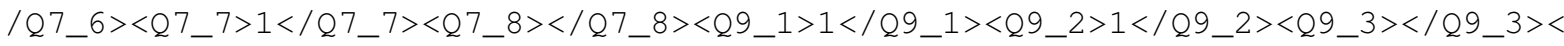
Q9_4 $>1</ 09 \_4><09 \_5>1</ 09 \_5><09 \_6>1</ 09 \_6><09 \_7>1</ 09 \_7><09 \_8></ 09 \_8><08 \_1><$

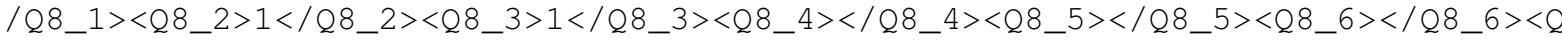

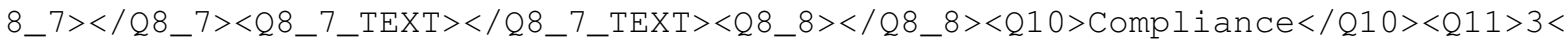
$/ \mathrm{Q} 11><\mathrm{Q} 12 \_1>1</ \mathrm{Q} 12 \_1><\mathrm{Q} 12 \_2></ \mathrm{Q} 12 \_2><\mathrm{Q} 12 \_3>1</ \mathrm{Q} 12 \_3><\mathrm{Q} 12 \_4>1</ \mathrm{Q} 12 \_4><\mathrm{Q} 12 \_5>$ $\left.1</ Q 12 \_5><Q 12 \_6></ Q 12 \_6><Q 12 \_6 \_\mathrm{TEXT}></ \mathrm{Q} 12 \_6 \_\mathrm{TEXT}\right\rangle\left\langle\mathrm{Q} 12 \_7></ \mathrm{Q} 12 \_7><\mathrm{Q} 13 \_1></ \mathrm{Q} 1\right.$

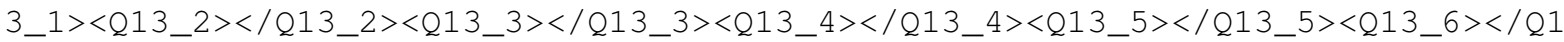

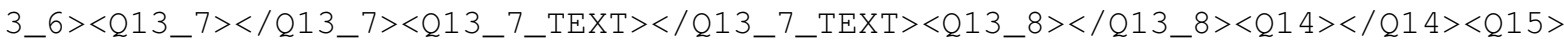
$3</ \mathrm{Q} 15><\mathrm{Q} 17>4</ \mathrm{Q} 17><\mathrm{Q} 18>2</ \mathrm{Q} 18><\mathrm{Q} 19>2</ \mathrm{Q} 19><\mathrm{Q} 20>2</ \mathrm{Q} 20><\mathrm{Q} 21>1</ \mathrm{Q} 21><\mathrm{Q} 22>1</$ Q22 $><223>1</ Q 23><Q 24></ Q 24></$ Response $>$

$<$ Response $><$ ResponseID $>$ R_1ANI6gpx2tPA01C $</$ ResponseID $><$ ResponseSet $>$ DefaultRes ponseSet $</$ ResponseSet $><$ Name $>$ Anonymous $</$ Name $><$ ExternalDataReference $></$ Extern alDataReference $><$ EmailAddress $></$ EmailAddress $><$ IPAddress $>58.84 .237 .67</$ IPAdd ress $><$ Status $>0</$ Status $><$ StartDate $>2011-03-11$

$12: 08: 29</$ StartDate $><$ EndDate $>2011-03-11$

$12: 12: 08</$ EndDate $><$ Finished $>1</$ Finished $><$ Q $1>$ Records

Specialist $</ Q 1><Q 2>4</ Q 2><Q 3>5</ Q 3><Q 4>4</ Q 4><Q 5>1</ Q 5><Q 6>1</ Q 6><Q 7 \_1>1</ Q$

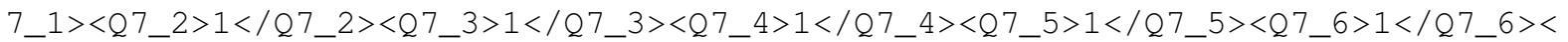
Q7_7 $>1</ 07 \_7><07 \_8></ 07 \_8><09 \_1>1</ 09 \_1><09 \_2>1</ 09 \_2><09$ 3 $>1</ 09 \_3><09 \_4><$

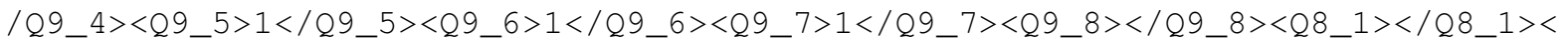

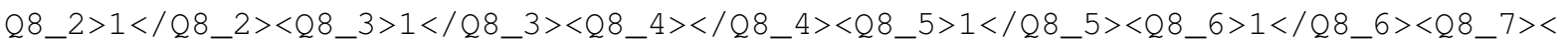

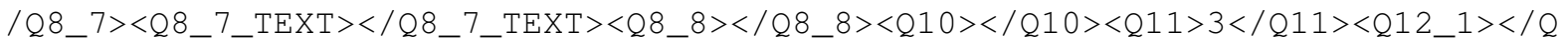
$12 \_1><Q 12 \_2></ Q 12 \_2><Q 12 \_3></ Q 12 \_3><Q 12 \_4></ Q 12 \_4>\left\langle Q 12 \_5></ Q 12 \_5><Q 12 \_6></ Q\right.$

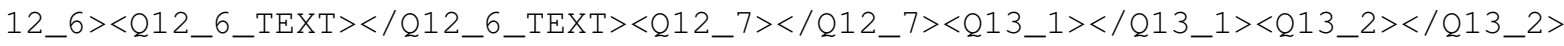

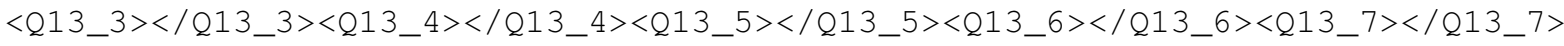

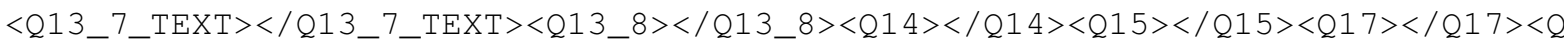

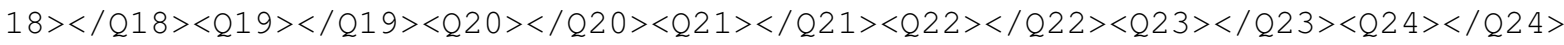
$</$ Response $>$

$<$ Response $><$ ResponseID $>$ R_COXPTjG9I8nWTIM $</$ ResponseID $><$ ResponseSet $>$ Default ResponseSet $</$ ResponseSet $><$ Name $>$ Anonymous $</$ Name $><$ ExternalDataReference $></$ Ext ernalDataReference $><$ EmailAddress $></$ EmailAddress $><$ IPAddress $>210.48 .109 .11</$ I PAddress $><$ Status $>0</$ Status $><$ StartDate $>2011-03-11$

$12: 08: 17</$ StartDate $><$ EndDate $>2011-03-11$

$12: 15: 14</$ EndDate $><$ Finished $>1</$ Finished $><Q 1>$ Informationmanager $</ Q 1><Q 2>5</ Q$ $2><Q 3>5</ Q 3><Q 4>5</ Q 4><Q 5>2</ Q 5><Q 6>1</ Q 6><Q 7 \_1>1</ Q 7 \_1><Q 7 \_2>1</ Q 7 \_2><Q 7 \_3$

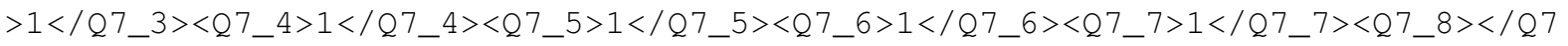

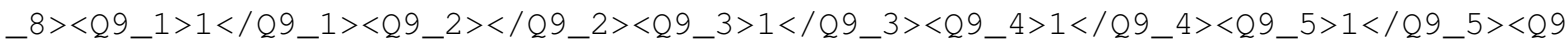

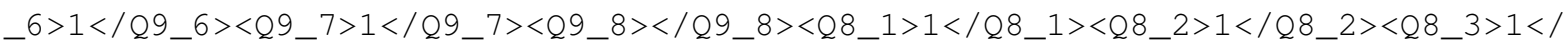

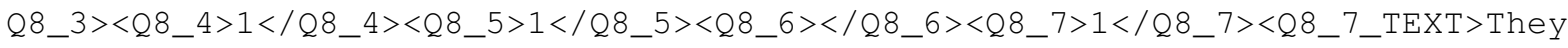
are being brought on board in a softly softly approach rather than

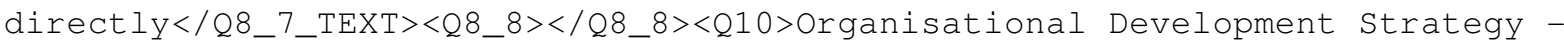
Working with others, Building One Agency, Driving performance excellence, providing quality

information $\langle/ \mathrm{Q} 10\rangle\left\langle\mathrm{Q} 11>2</ \mathrm{Q} 11><\mathrm{Q} 12 \_1>1</ \mathrm{Q} 12 \_1><\mathrm{Q} 12\right.$ _2 $></ \mathrm{Q} 12 \_2><\mathrm{Q} 12 \_3>1</ \mathrm{Q} 12 \_3$ $>\left\langle\mathrm{Q} 12 \_4>1</ \mathrm{Q} 12 \_4>\left\langle\mathrm{Q} 12 \_5>\left\langle/ \mathrm{Q} 12 \_5\right\rangle\left\langle\mathrm{Q} 12 \_6>\left\langle/ \mathrm{Q} 12 \_6>\left\langle\mathrm{Q} 12 \_6 \_\mathrm{TEXT}\right\rangle\left\langle/ \mathrm{Q} 12 \_6 \_\mathrm{TEXT}\right\rangle\langle\mathrm{Q} 1\right.\right.\right.\right.$ 2_7 $></ Q 12 \_7><Q 13 \_1></ Q 13 \_1><Q 13 \_2></ Q 13 \_2><Q 13 \_3></ Q 13 \_3><Q 13 \_4></ Q 13 \_4><Q 1$ 


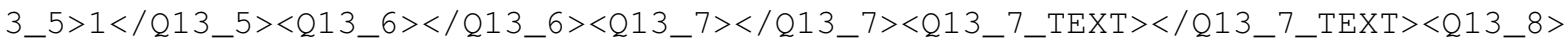
$</ Q 13$ _8 $><$ Q14 $>$ Everything else!! However I would say that we are winning, we have probably created more demand to do things right then we have resources to train the business to do things

right $</ \mathrm{Q} 14><\mathrm{Q} 15>3</ \mathrm{Q} 15><\mathrm{Q} 17>4</ \mathrm{Q} 17><\mathrm{Q} 18>2</ \mathrm{Q} 18><\mathrm{Q} 19>2</ \mathrm{Q} 19><\mathrm{Q} 20>2</ \mathrm{Q} 20><\mathrm{Q} 21$ $>3</ Q 21><Q 22>1</ Q 22><Q 23>1</ Q 23><Q 24>$ They are being utilised, but not formally. Utilising them formally is in my programme of work. $</$ Q24 $></$ Response $></$ xml $>$ 
Name: Grace Currie

Student Number: 300206190

Submission Date: 07/06/2011

Word Count: 8,316 (excluding appendices, bibliography and contents pages) 